Article

\title{
Dynamic Trends of Carbon Intensities among 127 Countries
}

\author{
Yu Sang Chang ${ }^{1}$, Dosoung Choi ${ }^{2}$ and Hann Earl Kim ${ }^{2, *}$ \\ 1 Gachon Center for Convergence Research, Gachon University, 1342 Seongnam-daero, Sujung-gu, \\ Gyeonggi-do 13120, Korea; ysc999@gachon.ac.kr \\ 2 Department of Global Business, Gachon University, 1342 Seongnam-daero, Sujung-gu, \\ Gyeonggi-do 13120, Korea; choids@gachon.ac.kr \\ * Correspondence: hk3624@gachon.ac.kr; Tel.: +82-31-750-5221
}

Received: 10 November 2017; Accepted: 5 December 2017; Published: 7 December 2017

\begin{abstract}
Many countries in the world have been experiencing widely varying rates of change in their carbon intensity $(\mathrm{CI})$ of economic output. The dynamic trend of $\mathrm{CI}$ in this research is measured by the progress ratio (PR) from an experience curve (EC) involving 127 countries during the period of 1980-2011. The overall average PR of $88.8 \%$ estimated for the total group of 127 indicates a decreasing trend of carbon intensity. This means that each doubling of the cumulative $\mathrm{CO}_{2}$ emission by this group has reduced carbon intensity by $11.2 \%$. While a majority of 83 countries experienced a decreasing trend with an average PR of $73.1 \%$, the remaining 44 countries have experienced an increasing trend with an average PR of $114.5 \%$. When two different types of EC, classical and kinked, were applied, 73 countries displayed a kinked slope with an average PR of $73.4 \%$, and 54 countries displayed a classical slope with an average PR of $104.2 \%$. Examination of the type of trend and slope of EC suggests the chance of a major improvement of the future CI in the following order: (1) the 35 countries with a classical slope and an increasing trend of CIs; (2) the nine countries with a kinked slope and an increasing trend of CIs; (3) the 19 countries with a classical slope and a decreasing trend of CIs; and (4) the 64 countries with a kinked slope and a decreasing trend of CIs. Further implications from these findings are discussed.
\end{abstract}

Keywords: carbon intensity of economic output; $\mathrm{CO}_{2}$ emissions; progress ratio; classical experience curve; kinked experience curve

\section{Introduction}

An increase of carbon emission in the world has continued each year, from the 22.7 billion tons of $\mathrm{CO}_{2}$ emitted in 1990 to the 36.3 billion tons in 2014. The first pause occurred in 2015 with an emission of 36.2 billion tons, a reduction of 0.1 billion tons [1]. However, the overall trend of global carbon emissions does not reveal the pervasive dynamic changes that individual countries experience in their carbon emission trends. For example, the four major countries-China, the United States, India, and Japan-have emitted a combined total of 19.7 billion tons of $\mathrm{CO}_{2}$ in 2015 , accounting for $54.42 \%$ of the global emissions. During the 25-year period from 1990 to 2015, China's emissions exceeded that of the United States for the first time in 2005, making China the largest producer of carbon emissions. Continuing a rapidly increasing trend, China's emission output grew to 10.7 billion tons, which was over twice the output of the United States (at 5.2 billion tons) by 2015. Similarly, India's emissions exceeded that of Japan in 2006. Additionally, by 2015, India's output of 2.5 billion tons was nearly twice that of Japan's output of 1.3 billion tons. These examples indicate that many countries in the world have changed their emission output rankings during the same period because of different rates of emission experienced by countries. 
Among the large number of carbon emission influencing factors [2-5], the growth rate of a country may be the most important common influencing factor that affects emission outputs of every country. For that reason, the carbon intensity (CI) of economic output is widely used as the measure of comparing the carbon emission trends of multiple countries with different sized GDPs [3]. Despite a large number of studies adopting CIs as the measure of the carbon emission trends, a few issues still remain underexplored. First, most of the previous studies tend to focus on a specific country [6], a small number of countries [4], or multiple regions [5]. Zhu et al.'s article, examining the CI trend of 89 countries for three decades, is a rare exception. By analyzing the CI trend of 127 countries from 1980 to 2011, this study provides a comprehensive picture covering the countries that used to be either excluded or classified as RoW (Rest of World) [3]. Second, those studies focusing on the direction and speed of the CI change (examining the long-term CI trend) typically measure the CI change with a simple averaged annual rate [3]. While the average annual change is a useful way to demonstrate the long-term trend, it fails to capture the dynamic nature of change during the period. This research employs the experience curve (EC) methodology to address this issue. The progress ratio (PR) of the EC represents the rate of change for $\mathrm{CI}$ as a function of doubling cumulative carbon emission for individual countries. By using two types of EC, classical and kinked, we examine not only the rate of change for Cis, but also the multiple rates of CI change, if any.

Our analysis identifies better performing countries which have reduced CI from poorly performing countries which have increased CIs. The results not only show the list of countries that are likely to continue their decreasing trend of $\mathrm{CI}$ in the future, but also suggest which countries may be likely to reduce their future CI by breaking away from their past trends of increasing CI. To the best of our knowledge, using EC to estimate PRs of CIs for more than 100 countries has not been reported in the literature. Therefore, this research may present a new contribution in the carbon emission literature.

Following this introduction, this paper is organized into the following six sections. Section 2 presents a brief review of past studies on the trends of CIs for multiple countries. Section 3 presents a brief review of EC applications in the energy field. Section 4 explains the data and method used. Description of the results follows in Section 5. Finally, the conclusion and limitations of our findings are discussed in Section 6.

\section{Background Information on Carbon Intensity of Economic Output (CI)}

The use of $\mathrm{CI}$ instead of carbon emission will make for a more meaningful comparison among countries with different-sized GDPs. By factoring out the varying sizes of national economies, the use of $\mathrm{CI}$ enables the focus of the analysis to be on other factors such as different structures and productivities of the economy, different resource endowment, different past climate action, and other policies adopted by the respective countries. For example, the difference of carbon emissions in 2015 between China's 10.7 billion tons over Japan's 1.3 billion tons was about $823 \%$ higher. However, comparing the measures in CI, the difference is reduced to $184 \%$ higher with China's CI of 0.475 versus Japan's 0.257 . Between the United States and Japan, the difference of emission in 2015 was $400 \%$ higher for the United States, whereas the difference in CI was only $12 \%$ higher. Here, the CI for the United States and Japan was 0.301 and 0.257 , respectively. These CIs are measured in metric tons per 1000 Purchasing Power Parity (ppp) 2005 dollars.

The static concept of CI for a given year can be converted into a dynamic concept by expressing the rate of change from the previous year to a given year. The same process can also convert GDP and carbon emission into a dynamic concept. Table 1 shows how the annual \% change in $2015 \mathrm{CI}$ and 2015 real GDP in ppp dollars during 2014-2015 are combined to yield the \% change of 2015 carbon emission for four major countries. For example, China had reduced their CI by $6.4 \%$ from 2014 to 2015. However, because the real GDP growth of $6.9 \%$ in 2015 was higher than the $6.4 \%$ reduction in CI, China ended up increasing their carbon emissions by $0.04 \%$. On the other hand, Japan had reduced their carbon emissions by $2.3 \%$ in 2015 due to the combined effect of their low GDP growth rate of 
$0.5 \%$ and a high $-3.0 \%$ reduction of CI. The second to the last column in Table 1 lists the 15-year trend of the annual average change of CI from 2000-2015. China and the United States are tied with a $-2.4 \%$ reduction rate, followed by India's $-1.5 \%$ and Japan's $-0.9 \%$.

Table 1. Rate of change for 2015 carbon intensity of economic output (CI) for four major countries.

\begin{tabular}{ccccccc}
\hline & $\begin{array}{c}\text { CI (2015) Metric } \\
\text { ton per 1000 ppp } \\
\text { 2005 Dollars }\end{array}$ & $\begin{array}{c}\text { Real GDP } \\
\text { Growth Rate } \\
\mathbf{2 0 1 4 - 2 0 1 5}\end{array}$ & $\begin{array}{c}\text { Change in } \\
\text { 2015 CI } \\
\text { from 2014 }\end{array}$ & $\begin{array}{c}\text { Change in } \\
\text { 2015 Emission } \\
\text { from 2014 }\end{array}$ & $\begin{array}{c}\text { Annual Average } \\
\text { Change } \\
\text { (2000-2015) }\end{array}$ & $\begin{array}{c}\text { 2015 Emission } \\
\text { (in Billion tons) }\end{array}$ \\
\hline China & 0.475 & $6.90 \%$ & $-6.40 \%$ & $0.04 \%$ & $-2.40 \%$ & 10.70 \\
US & 0.301 & $2.30 \%$ & $-4.30 \%$ & $-2.40 \%$ & $-2.40 \%$ & 5.20 \\
India & 0.276 & $7.60 \%$ & $-1.50 \%$ & $5.40 \%$ & $-1.50 \%$ & 2.50 \\
Japan & 0.257 & $0.50 \%$ & $-3.00 \%$ & $-2.30 \%$ & $-0.90 \%$ & 1.30 \\
World & 0.295 & $3.10 \%$ & $-1.30 \%$ & $0.20 \%$ & $-1.30 \%$ & 36.20 \\
\hline
\end{tabular}

Source: Olivier et al. [1].

How pervasive and consistent are the decreasing trends of CIs shown by these four countries when the analysis is expanded to include multiple countries? Using data available from a couple of yearly issues from the Low Carbon Economy Index [7,8], Table 2 presents the historical data of CIs for 19 major countries in the world for the years of 1990, 2000, 2008, and 2015. First, it can be observed that every country has displayed a decreasing trend of CI when the CIs are compared between 1990 and 2015. However, there is a wide variation in the reduction of CIs among the countries. For example, China recorded the highest reduction at 73\%, whereas the reduction by Korea was the smallest at $7 \%$, followed by Turkey's 22\% reduction. Another important observation is that five out of the 19 countries have recorded an increasing trend between 1990 and 2000 and then begun a declining trend from 2000 to 2015. For example, Indonesia showed the largest fluctuating trends when its 1990s CI of 0.32 increased to 0.42 by 2000, followed by a decreasing trend that reached 0.39 in 2008 before finally decreasing to 0.208 by 2015 . There are three other countries-Brazil, Korea, and Turkey-which also displayed fluctuating trends of CIs. Japan also recorded a moderate increase from 0.31 in 1990 to 0.32 in 2000, followed by a decline to 0.30 in 2008 and 0.257 by 2015. Saudi Arabia is the only country with an increasing trend from 0.63 in 1990 to 0.68 in 2000 and 0.77 by 2008, followed by a sharp declining trend that reached 0.411 by 2015 .

Table 2. Historical CI for 19 major countries (1990, 2000, 2008, 2015) *.

\begin{tabular}{ccccc}
\hline & $\mathbf{1 9 9 0}$ & $\mathbf{2 0 0 0}$ & $\mathbf{2 0 0 8}$ & $\mathbf{2 0 1 5}$ \\
\hline China & 1.73 & 0.88 & 0.83 & 0.475 \\
US & 0.60 & 0.50 & 0.42 & 0.301 \\
India & 0.50 & 0.47 & 0.40 & 0.276 \\
Japan & 0.31 & 0.32 & 0.30 & 0.257 \\
France & 0.25 & 0.22 & 0.19 & 0.121 \\
Italy & 0.27 & 0.26 & 0.24 & 0.153 \\
UK & 0.41 & 0.31 & 0.25 & 0.157 \\
Brazil & 0.19 & 0.22 & 0.21 & 0.157 \\
Argentina & 0.31 & 0.30 & 0.27 & 0.190 \\
Germany & 0.45 & 0.32 & 0.28 & 0.195 \\
Mexico & 0.29 & 0.27 & 0.27 & 0.206 \\
Turkey & 0.27 & 0.30 & 0.27 & 0.211 \\
Indonesia & 0.32 & 0.42 & 0.39 & 0.208 \\
Australia & 0.61 & 0.54 & 0.47 & 0.347 \\
Canada & 0.59 & 0.55 & 0.50 & 0.351 \\
Saudi Arabia & 0.63 & 0.68 & 0.77 & 0.411 \\
Russia & 1.30 & 1.05 & 0.68 & 0.418 \\
Korea & 0.45 & 0.52 & 0.46 & 0.419 \\
South Africa & 1.07 & 1.05 & 0.94 & 0.583 \\
\hline * In metric ton per 1000 ppp 2005 dollars; Source: PwC [7,8].
\end{tabular}


Implications from these examples indicate that changing trends of CIs for multiple countries may display not only a greater degree of fluctuating trends, but may also include countries that follow increasing trends of CIs throughout the entire period. The literature analyzing CIs deals mainly with individual countries or sectors within a country [9-13]. An exception is the article by Zhu et al., which analyzed declining rates of CIs for 89 countries from 1980 to 2008 [3]. However, the declining rate is measured by a simple averaged annual rate during the period. In contrast, the rate of change of CIs in this research will be measured by PR from the experience curve methodology. In fact, this research will use two types of experience curves, the classical and kinked models. More specifically, this research will estimate and rank the historical rates of change for $\mathrm{CI}$ involving 127 countries during the period of 1980-2011. The resulting PR represents the rate of change for CI as a function of doubling cumulative carbon emission for individual countries. Varying rates of change for CI for multiple countries will require that the model to be used should be able to track both increasing and decreasing trends. Moreover, the model will also need to estimate multiple rates of change over a life-cycle. The experience curves to be used have these capabilities.

\section{Experience Curve Applications in Energy}

Even though the first industrial application of EC took place early in the 1930s [14], the active application of EC for carbon emissions and energy technologies did not begin until the 1990s. The first application of ECs to analyze CI of economic output was made in the late 1990s by Nakicenovic [15]. Using data available for the United States during the period of 1850-1900, the declining trend of CIs was analyzed as a function of cumulative $\mathrm{CO}_{2}$ emissions by EC. The resulting negative experience slope was estimated and yielded a PR of $76 \%$, indicating that each doubling of cumulative $\mathrm{CO}_{2}$ emissions generated a $24 \%$ reduction in CI. This finding showed that a significant decarbonization of the U.S. economy has taken place during this period. A similar study was later repeated [16] showing that a PR of 79\% was estimated for the economy of the whole world using EC. More recently, ECs have been applied to climate control, renewable energy, and other environmental issues. A review article by Weiss et al. [17] presented the PR for 75 energy-demand technologies with an average PR of $82 \%$. Another group of 132 studies on energy supply technologies [18-20] yielded an average PR of $84 \%$. Still another recent article [21] reviewed PRs for 11 power-generating technologies. Until now, however, no article analyzing CI for as many as 100 countries by the use of ECs has appeared in the literature, to our best knowledge.

Why do performance metrics such as CI typically follow a decreasing trend displaying an improvement pattern as a function of cumulative experience? According to recent learning and experience curve theories [20,22], the observed improvements are the cumulative results of a multitude of learning processes. In addition to learning by workers, from scaling and researching, learning by interactions and knowledge spill-over effects [23], learning by usage and consumption [24], and learning by learning [25] are also important learning processes. In short, the use of cumulative experience as an independent variable provides a rich conceptual explanation to the improvement outcomes of performance metrics, compared to the use of simple time as an independent variable in trend analysis. Furthermore, the rate of change in the performance outcomes in EC is related to the rate of change of cumulative experience. Since the rate of change of cumulative experience over a time period can vary for multiple reasons, the rate of change for performance outcome can also vary over a time period, thus providing a more flexible mechanism of estimating fluctuating PR.

When the trend of the performance metric is increasing rather than decreasing, ECs are capable of analyzing such cases as well. For example, Grubler [26] used ECs to estimate the positive experience slope for increasing reactor construction costs per KW for nuclear power as a function of cumulative installed capacity in both France and the United States. A positive experience slope translates into the value of a PR which exceeds $100 \%$. Similarly, positive experience slopes have been reported for natural gas-fired power-plants [27] as well as on-shore wind power [28]. 
Learning rates are typically not the same throughout the life-cycle of a technology [29]. Sometimes, such changes in the slope are caused by technological breakthroughs [30]. In other cases, experience slopes became steeper in the later development stages of several renewable energy technologies [31]. Under these circumstances, traditional ECs can be modified to accommodate multiple experience slopes over a life-cycle. Such modified ECs, known as kinked ECs, with a kink (piecewise linear) in the slope, have been used in several studies [17,31-34]. Further explanation and application of the kinked model can be found in a review article by Chang and Lee [35].

In summary, ECs can deal with both increasing and decreasing trends of performance outcomes such as CI. ECs are also capable of estimating multiple rates of change over a life-cycle period. Compared to the use of time as independent variable, ECs are a more flexible alternative method of estimating the rate of change of performance outcomes.

\section{Data and Method}

Instead of using the traditional Kaya identity [36], we bypassed the process of estimating the carbon intensity of energy supply and energy intensity, and made a direct estimate of carbon intensity of economic output (CI). The CI measures used in this paper originate from the data series of the Energy Information Administration (EIA). CI is defined as the total carbon dioxide emission $\left(\mathrm{TCO}_{2}\right)$ divided by GDP. The unit for $\mathrm{CI}$ is in metric tons of carbon dioxide per 2005 Purchasing Power Parity (ppp) thousand U.S. dollars. The unit for total carbon dioxide emission is in millions of metric tons. $\mathrm{CI}$ is obtained from the EIA's International Energy Statistic website [37].

Our classical EC equation of carbon intensity is:

$$
y\left(x_{t}\right)=a x_{t}^{b}
$$

where $t=1980,1981,1982, \ldots, 2011, y\left(x_{t}\right)$ represents CI in year $t, x_{t}$ represents the cumulative volume of carbon dioxide emission from year 1980 through year $t$, and $a, b=$ parameters for Equation (1).

The kinked experience equations for the carbon intensity are defined if we have a break point at the year $k$ like the following:

$$
y\left(x_{t}\right)=a x_{t}^{b 1}
$$

where $a_{1}$ and $b_{1}$ are parameters for Equation (2) $(t=1980,1981, \ldots, k-1)$, and

$$
y\left(x_{t}\right)=a x_{t}^{b 2}
$$

where $a_{2}$ and $b_{2}$ are parameters for Equation (3) $(t=k, k+1, \ldots, 2011)$.

The PR for cumulative doubling of $\mathrm{CO}_{2}$ emissions is derived through the equation $\mathrm{PR}=2^{b}$. The learning rate (LR) is defined as $L R=1-P R$. In logarithmic form, the classical experience equation is expressed as:

$$
\ln y\left(x_{t}\right)=\ln a+b \ln x_{t}
$$

The kinked experience equation for the first period can be expressed as:

$$
\ln y\left(x_{t}\right)=\ln a_{1}+b_{1} \ln x_{t}
$$

The kinked experience equation for the second period can be expressed as:

$$
\ln y\left(x_{t}\right)=\ln a_{2}+b_{2} \ln x_{t}
$$

We are able to combine the two kinked experience Equations, Equations (5) and (6), using a dummy variable which has a value of 1 if the year falls in the second period, and zero otherwise:

$$
\ln y\left(x_{t}\right)=\ln a_{1}+\left(\ln a_{2}-\ln a_{1}\right) \times p+b_{1} \log x_{t}+\left(b_{2} b_{1}\right) \log x_{t} \times p
$$


where $p=0$ if $t=1980,1981, \ldots, k-1, p=1$ if $t=k, k+1, \ldots, 2011$.

The breakpoint, $k$, is the year when a kink in the pattern of carbon intensity occurs. We assume all years are possibilities for the kinked year and compute the coefficient of determination $R^{2}$ of the kinked experience using Equation (7) for each candidate year. Then, we take the year with the largest $R^{2}$ as the kinked year. Thus, the kinked year is likely to vary by country.

Then, we test whether the difference between $b_{1}$ and $b_{2}$ is statistically significant. If the difference between $b_{1}$ and $b_{2}$ is not statistically significant, the classical EC should be used. If the difference between $b_{1}$ and $b_{2}$ is statistically significant, the kinked EC should be used.

The PR from the cumulative doubling of $\mathrm{TCO}_{2}$ is derived from the equation, $\mathrm{PR}=2^{b}$. In other words, PR represents the rate of change of $\mathrm{CI}$ as a function of the doubled cumulative $\mathrm{TCO}_{2}$. For example, if the PR is $80 \%$, then, each doubling of cumulative $\mathrm{TCO}_{2}$ will require $20 \%$ less CI. On the other hand, if the PR is $120 \%$, then, each doubling of cumulative $\mathrm{TCO}_{2}$ will require $20 \%$ more CI. Put in another way, if the historical trend of CI is decreasing, the PR will be less than $100 \%$. Under this circumstance, doubling the cumulative $\mathrm{TCO}_{2}$ will require a proportionately less $\mathrm{CI}$, indicating higher decarbonization. Conversely, if the historical trend of $\mathrm{CI}$ is increasing, the PR will be greater than $100 \%$, and doubling the cumulative $\mathrm{TCO}_{2}$ will require a proportionately greater $\mathrm{CI}$, indicating greater carbonization. Therefore, the PRs derived for different countries can indicate which countries have managed $\mathrm{CO}_{2}$ emission better to generate a constant unit of GDP over time and which countries have not. Additionally, PRs can be used to project future $\mathrm{CO}_{2}$ emission for respective countries as well.

We began with a total sample of 224 countries available from the EIA's website. However, some data was missing, so we eliminated 69 countries and ran an initial experience curve analysis on the remaining 155 countries. The results of our initial analysis showed 28 countries with PRs that were not statistically significant. Therefore, a final sample of 127 countries was used for analysis.

\section{Results}

The results of the PRs estimated from both the classical and the kinked experience curves are ranked from the lowest to the highest PR in Table A1. Zambia is ranked first with the lowest PR of $24.3 \%$, while Lebanon is ranked 127th with the highest PR of $159.3 \%$. Both PRs are derived from kinked experience curves and each PR is statistically significant, as shown in Table A1. In this ranking, China-which generated the largest amount of $\mathrm{CO}_{2}$ emissions-is ranked 43rd with a PR of $76.2 \%$, while the United States—which generated the second largest emissions—is ranked 36th with a PR of $72.7 \%$.

During the period of 1980-2012, each doubling of cumulative $\mathrm{CO}_{2}$ emissions has enabled China to generate $23.8 \%$ less $\mathrm{CO}_{2}$ emissions in producing a constant unit dollar of China's GDP. For the United States, each doubling of cumulative $\mathrm{CO}_{2}$ emissions has reduced $\mathrm{CO}_{2}$ emissions by $27.3 \%$ per constant unit dollar of GDP produced in the United States. India, which generated the third largest emission, is ranked 64th with a PR of $90.3 \%$.

The distribution of PRs for all 127 countries is displayed in a histogram in Figure 1. The average PR was $88.8 \%$. There were approximately 85 countries representing $67 \%$ of the 127 countries within the range of one standard deviation, which suggests that the overall pattern appears to follow an approximately normal distribution.

Then, the total group of 127 countries was divided into two subgroups of increasing and decreasing experience slopes. The decreasing subgroup contained 83 countries ranging from the top-ranked Zambia with a PR of $24.3 \%$ to the 83 rd ranked Japan with a PR of $97.7 \%$. The average PR of the decreasing subgroup was $75.13 \%$, as shown in Figure 2. The increasing subgroup contained 44 countries ranging from the 84th ranked Ecuador with a PR of $101.9 \%$ to the 127 th ranked Lebanon with a PR of $159.3 \%$. The average PR for this subgroup was $114.52 \%$, as shown in Figure 3. 


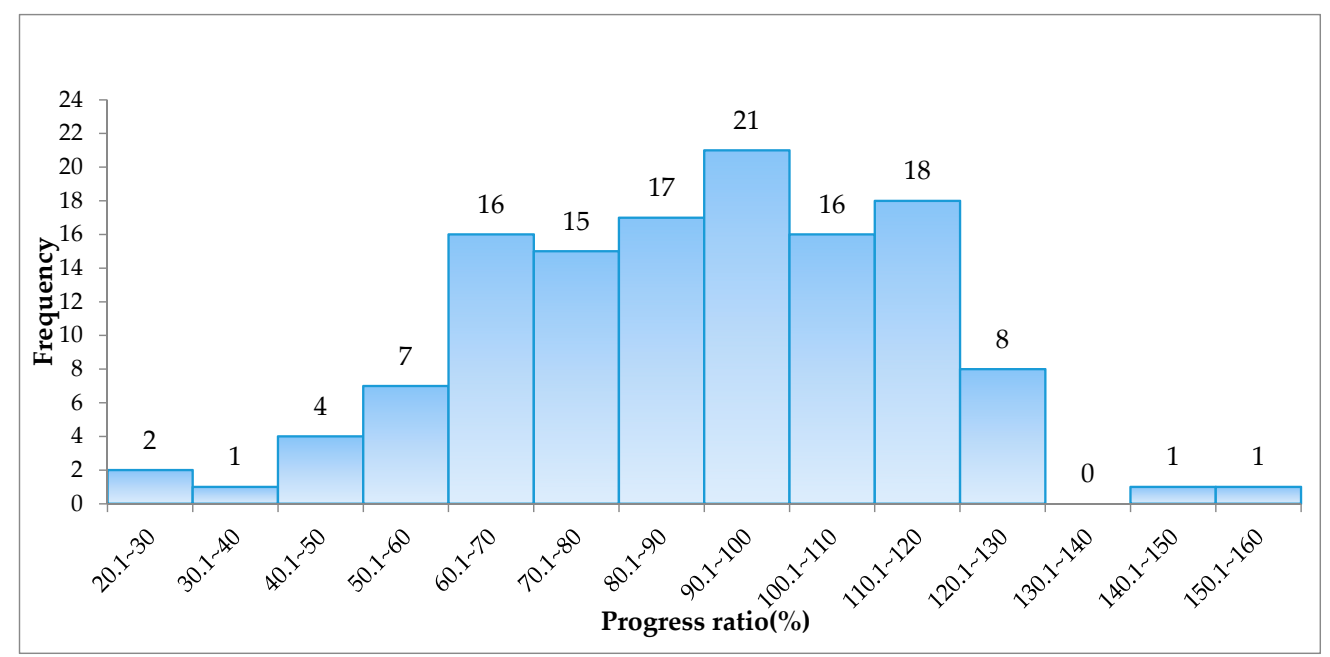

Figure 1. Histogram of progress ratios (PRs) from experience curve (EC) for CI of 127 countries.

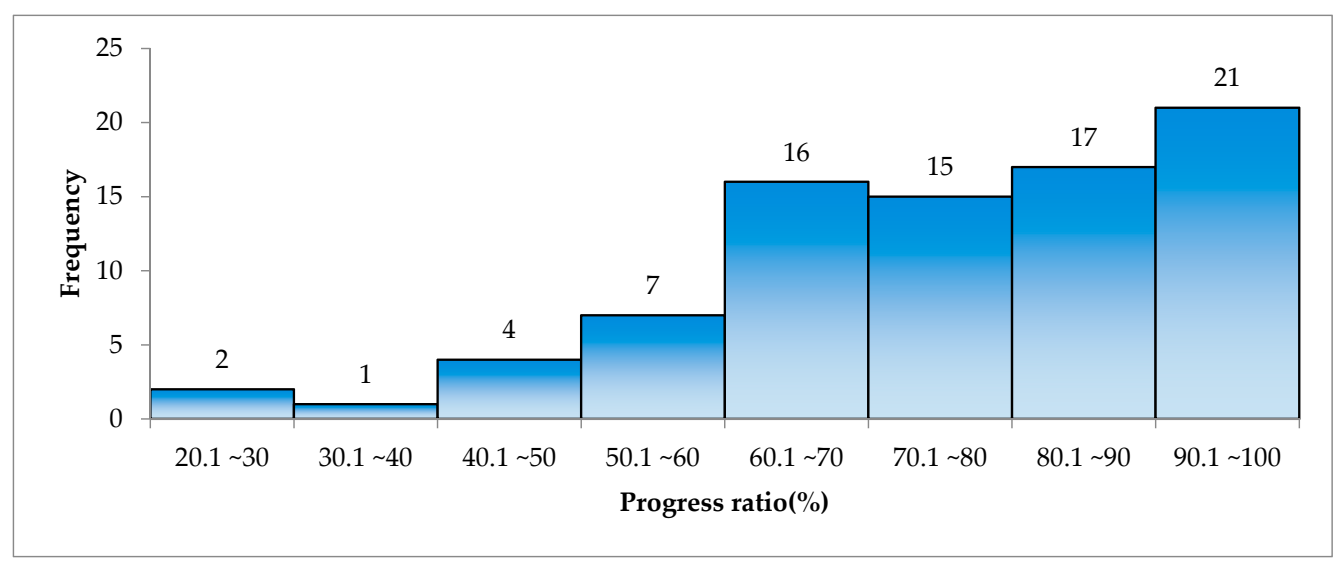

Figure 2. Histogram of PRs from EC for CI of 83 decreasing countries.

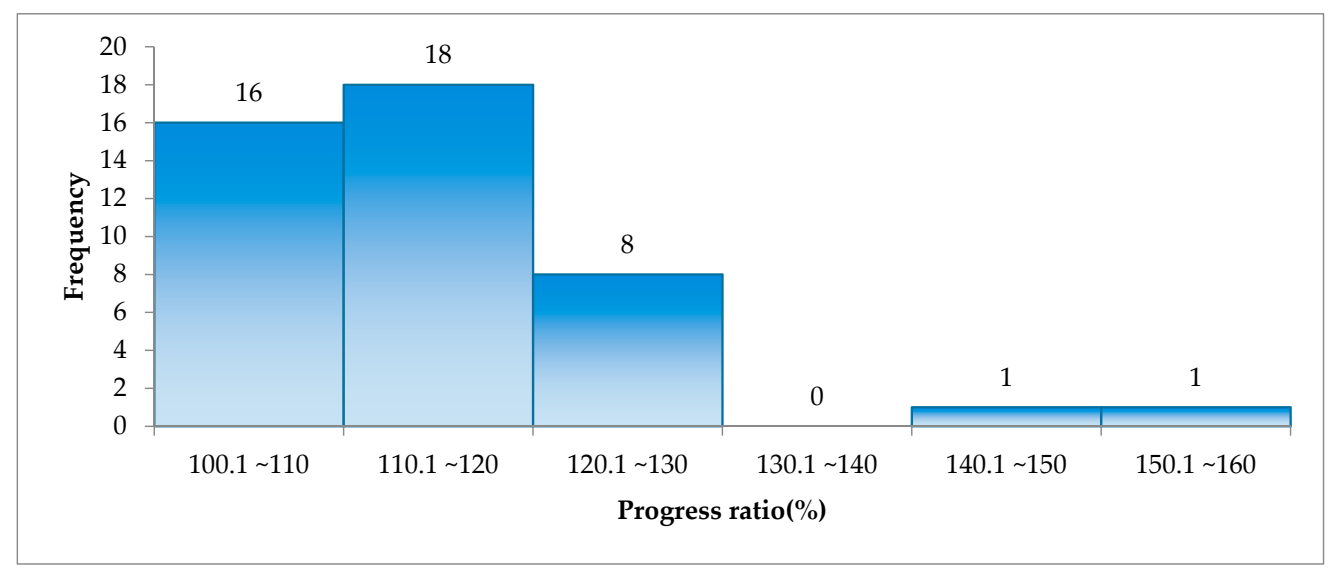

Figure 3. Histogram of PRs from EC for CI of 44 increasing countries.

Next, we divided the 127 countries into another two subgroups. The first subgroup contained 73 countries with experience curves represented by a kinked model. The average PR for the kinked subgroup was $73.38 \%$, as shown in Figure 4. The range of this kinked subgroup was the same range as the total group. In contrast, the remaining 54 countries were grouped into the second subgroup with experience curves represented by a classical model. 
The range of this subgroup was narrower, ranging from the 38th ranked Luxembourg with a PR of $73.2 \%$ to the 125 th ranked Haiti with a PR of $127.7 \%$. The average PR of this group was higher at $104.2 \%$, as shown in Figure 5.

Pooling the results of the analysis from the two separate subgroups of trends and slopes, the question to be examined deals with which subgroups of countries are more likely to break away from the past trend for a major improvement of their CIs in the future. The subgroup of the 83 countries with decreasing trend are less likely to produce a major improvement in the future because they have already made excellent progress in the past, as indicated by their average PR of $75.13 \%$. That leaves the subgroup of the 44 countries with an increasing trend. They have not kept abreast of the progress toward decarbonization as indicated by their average PR of $114.52 \%$, which is significantly higher than the average PR of all 127 countries at $88.8 \%$.

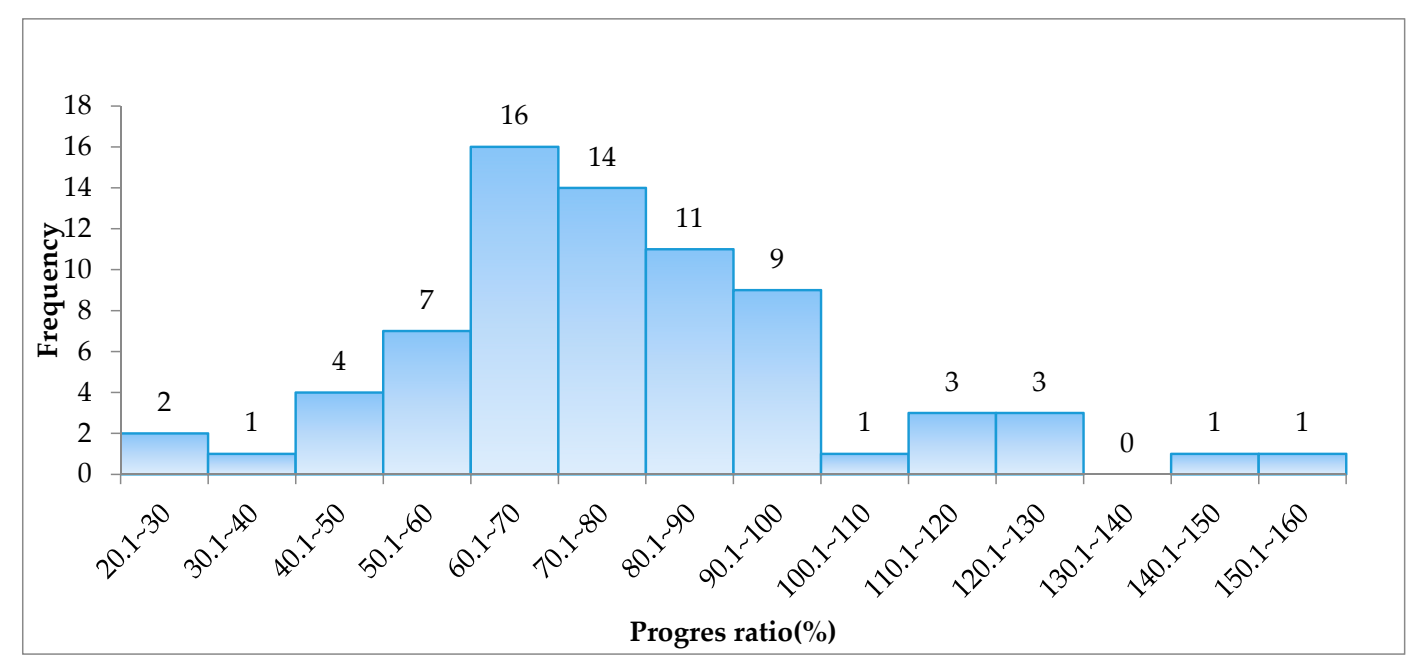

Figure 4. Histogram of PRs from EC for CI of 73 countries.

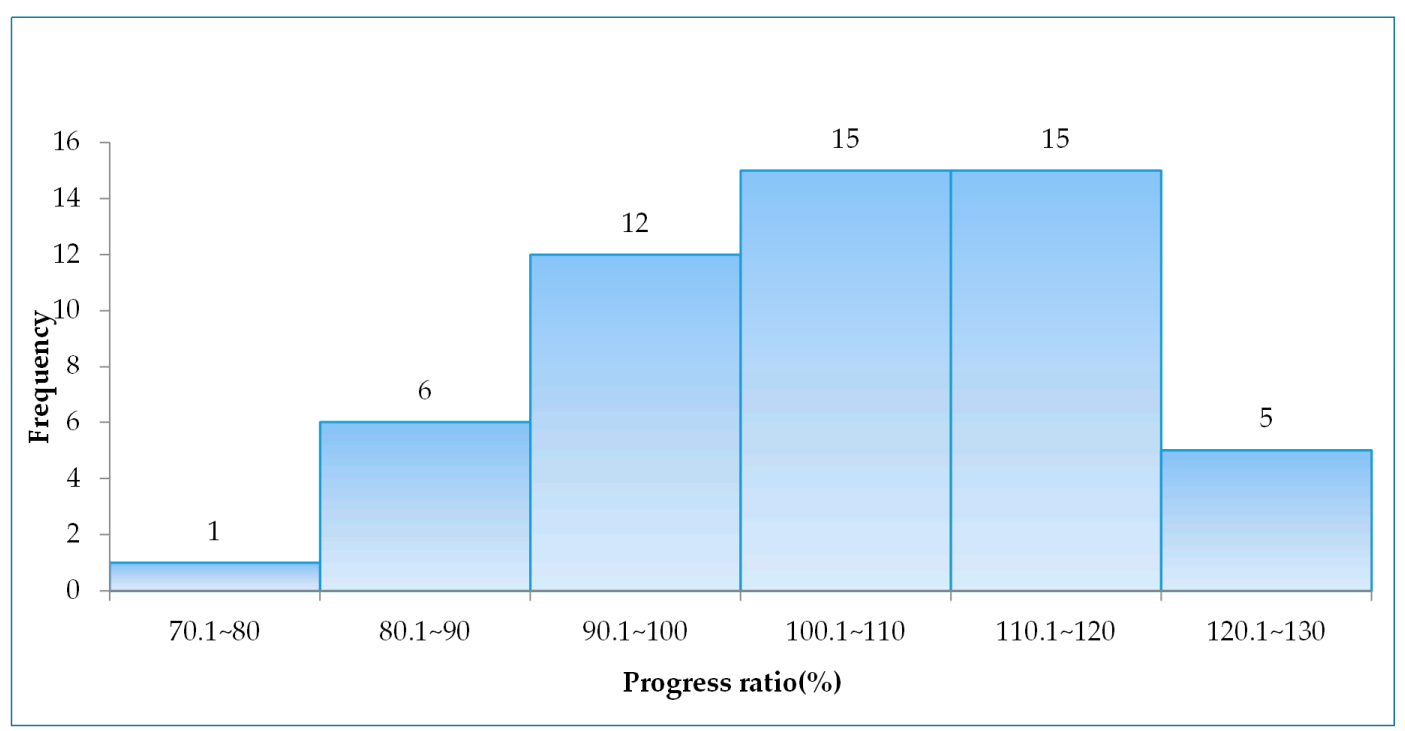

Figure 5. Histogram of PRs from EC for CI of 54 countries.

We further subdivided the subgroup of the 44 countries into two subgroups, one representing classical experience slopes and the other representing a kinked experience slopes. The average PR of the nine countries with a kinked slope was estimated at $125.68 \%$, while an average PR of $111.65 \%$ was estimated for the 35 countries with a classical slope, as shown in Table 3. As for the subgroup of 
83 countries with a decreasing trend, an average PR of $90.45 \%$ was estimated for the 19 countries with a classical slope, while the lowest average PR of $62.23 \%$ was estimated for the remaining 64 countries with a kinked slope, which are also shown in Table 3.

In order to highlight the differences existing among these four subgroups, experience curve diagrams for countries representing these four subgroups are displayed in Figures 6-9. Figure 6 shows the experience curve for Luxembourg, which represents a decreasing classical experience slope, while Figure 7 shows the experience curve for Togo, which represents an increasing classical experience slope. The value of the increasing classical slope for Togo is 0.284 while the value of the decreasing classical slope for Luxembourg is -0.45 . The former has a PR of $121.8 \%$, while the latter has a PR of $73.2 \%$. Each country is displayed as a single classical experience curve.

Figure 8 shows the experience curve for Zambia, which represents a decreasing kinked slope, while Figure 9 shows the experience curve for Lebanon, which represents an increasing kinked slope. Zambia displays two kinked slopes made up of the first slope covering the period of 1980-2003 and the second slope covering the period of 2004-2011. The second kinked slope has a steeper value of -2.043 while the first kinked slope has a moderate value of -0.297 . The PR from the second kinked slope for Zambia is $24.3 \%$. For Lebanon, the first kinked slope covers the period of 1980-2000, and the second kinked slope covers the period of 2001-2011. Once again, the second kinked slope has a steeper value of 0.6717 , while the first kinked slope has a moderate value of 0.1345 . The PR from the second kinked slope for Lebanon is $159.3 \%$.

In summary, a classical experience curve displays one slope for a given period, while a kinked experience curve displays two slopes during the given period. In general, the second kinked slope has a steeper value than the first slope. The kinked year, which begins a second kinked period, varies by country. Only the second kinked slope is used to estimate the PR for a given country.

Among these four subgroups, we selected the subgroup of the 35 countries with an increasing classical slope to have somewhat of a better chance at breaking away from their past trend for a major improvement in their CIs in the future. For example, they include countries like Congo ( $\mathrm{PR}=1.248$ ), Togo ( $P R=1.218)$, Guinea-Bissau ( $P R=1.216)$, Tonga ( $P R=1.209)$, Libya $(P R=1.182)$, and Comoros $(\mathrm{PR}=1.178)$. The second-best chances may exist for the subgroup of the nine countries with an increasing kinked slope. Some of the candidate countries in this group include Benin $(\mathrm{PR}=1.469)$, Maldives ( $\mathrm{PR}=1.272)$, Honduras ( $\mathrm{PR}=1.213)$, Tanzania $(\mathrm{PR}=1.21)$, Cambodia ( $\mathrm{PR}=1.177)$, Cape Verde $(\mathrm{PR}=1.152)$, and Thailand $(\mathrm{PR}=1.131)$.

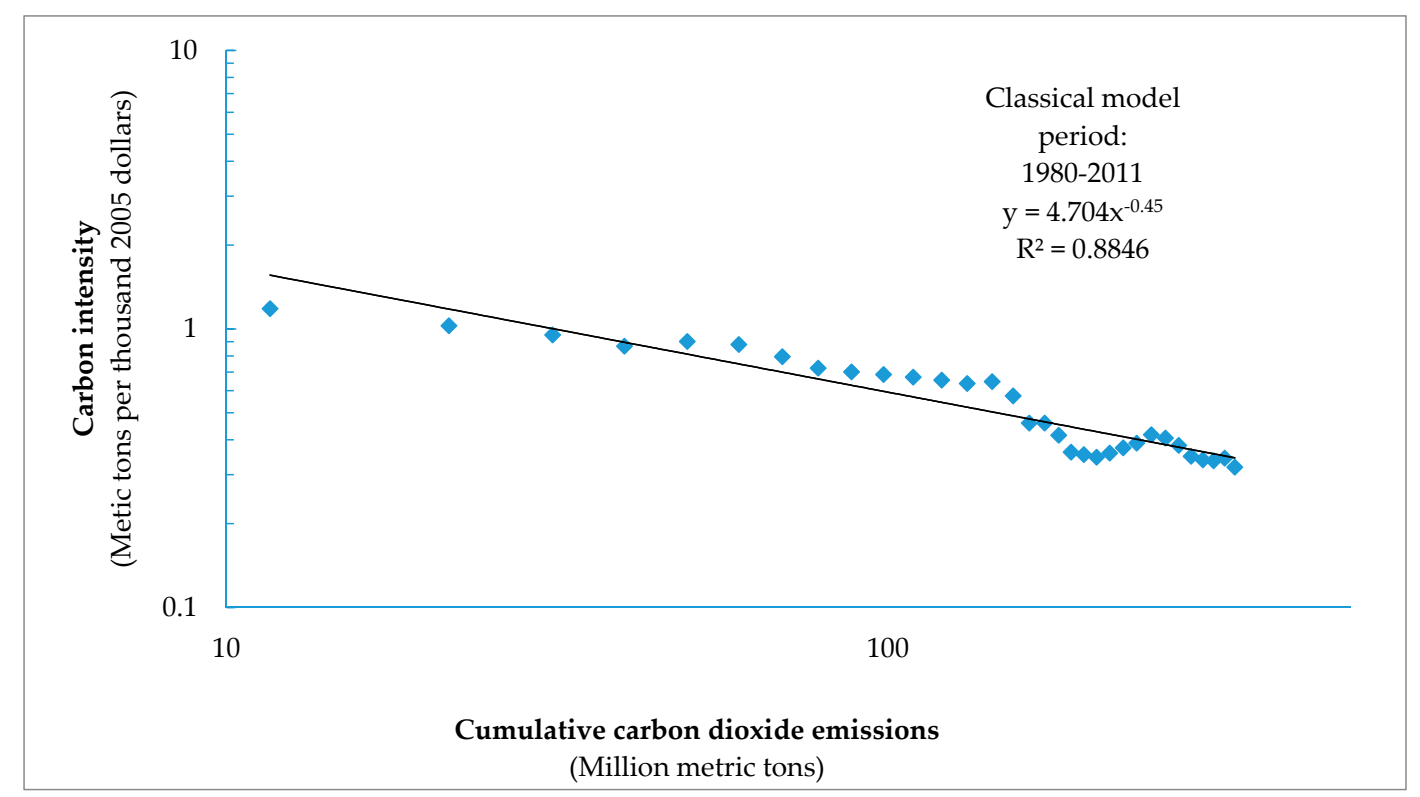

Figure 6. Decreasing classical EC (Luxembourg). 
Table 3. Trend versus experience slope of 127 countries.

\begin{tabular}{|c|c|c|c|c|}
\hline & Kinked Subgroup & Classical Subgroup & Total Group & \\
\hline Decreasing & $\begin{array}{c}62.23 \% \\
64\end{array}$ & $\begin{array}{c}90.45 \% \\
19\end{array}$ & $\begin{array}{c}75.13 \% \\
83\end{array}$ & $\begin{array}{c}\text { Average PR } \\
\text { Number of countries }\end{array}$ \\
\hline Increasing & $\begin{array}{c}125.80 \% \\
9\end{array}$ & $\begin{array}{c}111.65 \% \\
35\end{array}$ & $\begin{array}{c}114.52 \% \\
44\end{array}$ & $\begin{array}{c}\text { Average PR } \\
\text { Number of countries }\end{array}$ \\
\hline Total & $\begin{array}{c}77.38 \% \\
73\end{array}$ & $\begin{array}{l}104.20 \% \\
54\end{array}$ & $\begin{array}{c}88.80 \% \\
127\end{array}$ & $\begin{array}{c}\text { Average PR } \\
\text { Number of countries }\end{array}$ \\
\hline 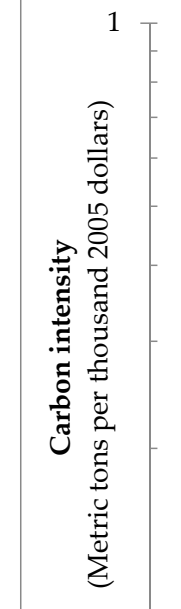 & $\bullet$ & $\begin{array}{c}\text { Classical mode } \\
\text { period: } \\
1980-2011 \\
\mathrm{y}=0.1073 \mathrm{x}^{0.284} \\
\mathrm{R}^{2}=0.4387\end{array}$ & $\overbrace{\rightarrow \infty}^{\infty}$ & + \\
\hline 0.1 & & $\begin{array}{l}1 \\
\text { mulative carbon dioxid } \\
\text { (Million metric to }\end{array}$ & missions & 100 \\
\hline
\end{tabular}

Figure 7. Increasing classical EC (Togo).

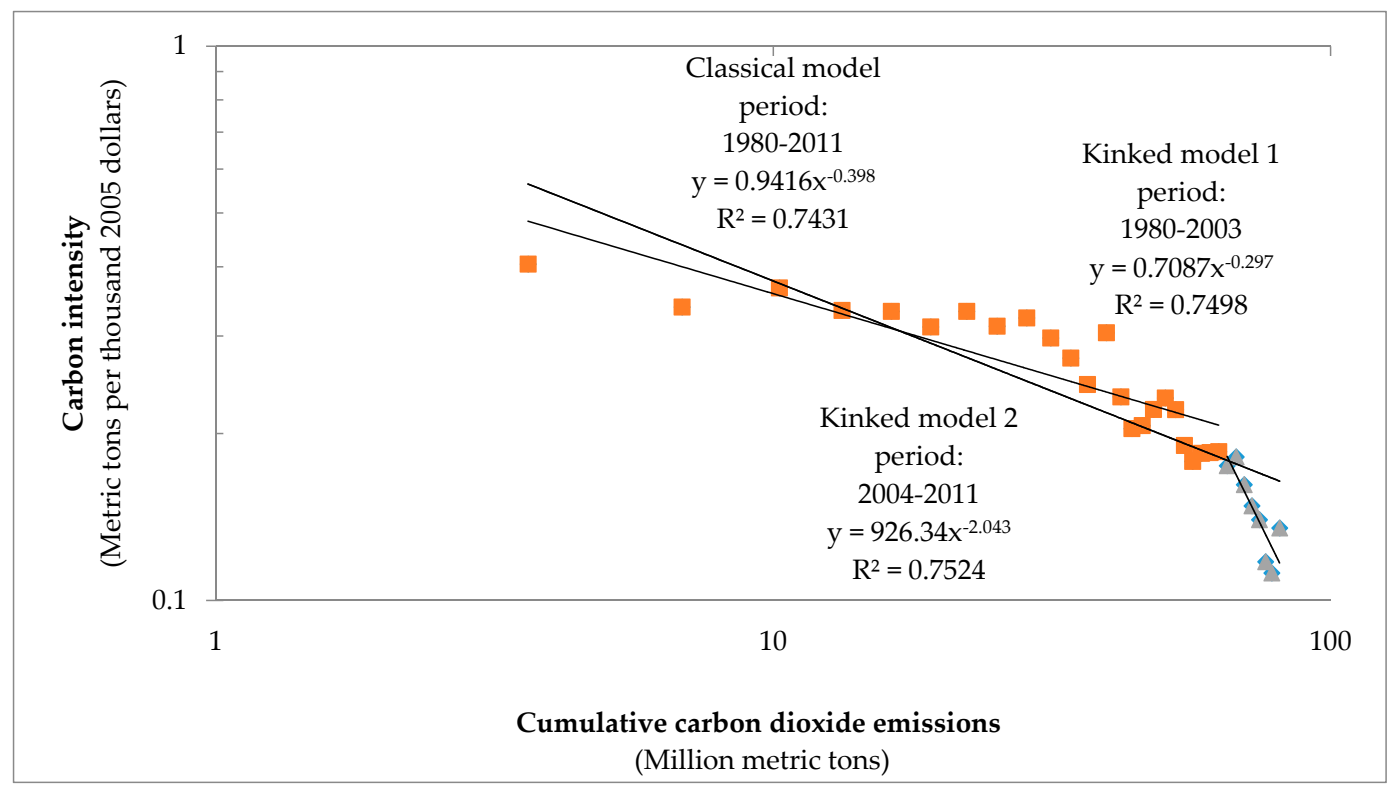

Figure 8. Decreasing kinked EC (Zambia). 
This selection is made in spite of the fact that the average PR of the increasing kinked subgroup $(125.68 \%)$ is higher than the average PR of the increasing classical subgroup (111.65\%). We believe that the cumulative experience of better managing $\mathrm{CO}_{2}$ emissions of a country will likely result in changing a currently increasing classical slope into a steep and decreasing kinked slope in the future.

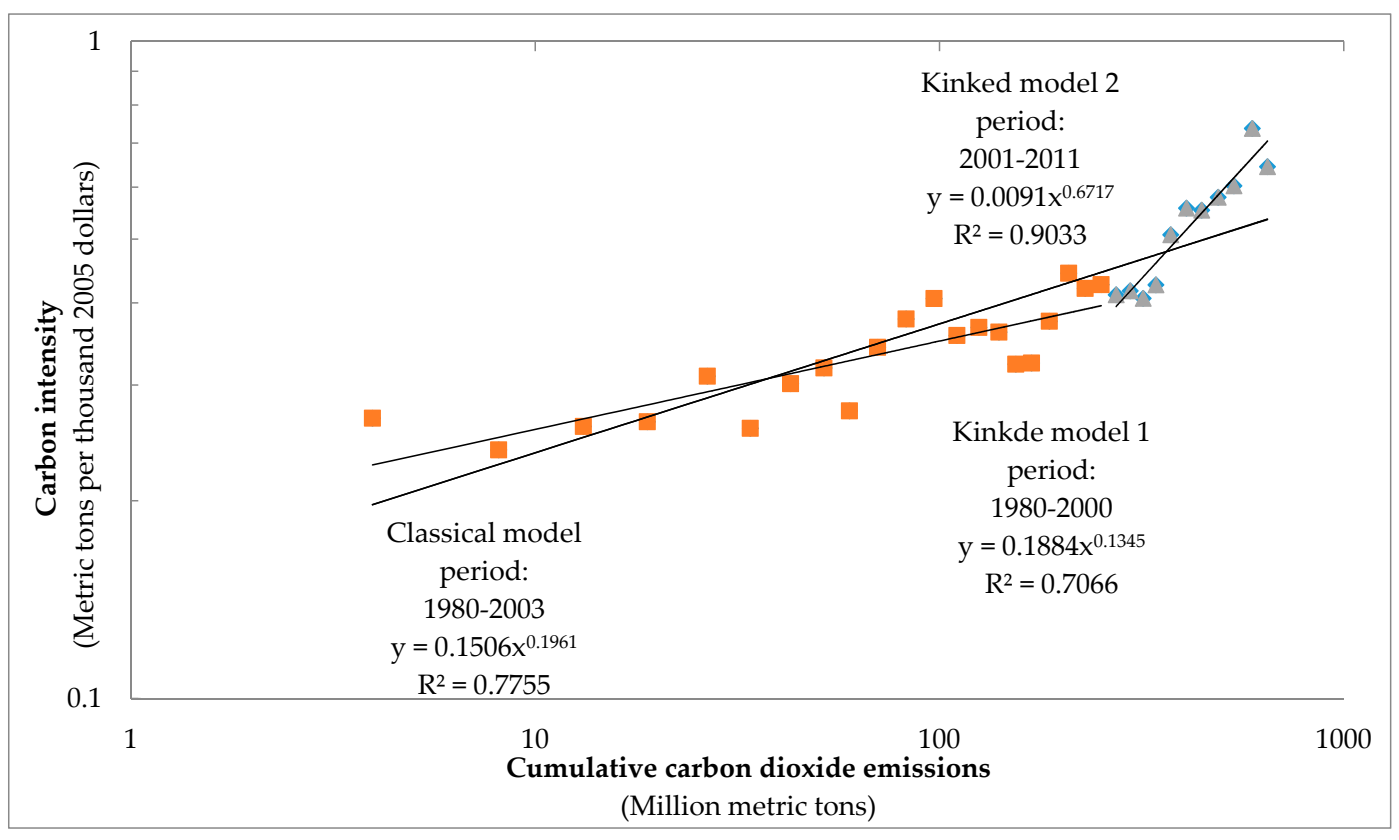

Figure 9. Increasing kinked EC (Lebanon).

On the other hand, the countries with an increasing kinked slope have already experienced one increasing kink in the past, so their current increasing kinked slope would need to be replaced by a decreasing second kinked slope. In this case, the chances of a second kink occurring may be somewhat less than the occurrence of a first kink, based on our experiences of working with many kinked slopes from other studies [38-41].

The subgroup of the 19 countries with a classical decreasing trend has an average PR of $90.45 \%$. It is quite possible that some of these countries such as Uruguay ( $P R=0.973)$, Kenya ( $P R=0.962)$, Sri Lanka $(P R=0.959)$, and Algeria $(P R=0.951)$ may realize a steeper kinked decreasing slope resulting in a major improvement in their CIs as well.

We then examine the next question as to whether countries in any particular region or income level were more likely to break away from their past trends to make a major improvement in their CIs in the future. First, we proceed with dividing the 127 countries into subgroups of six regions: America, Africa, Asia, Europe, Middle East, and Oceania, following a definition established by the World Health Organization in Table 4. Only the regions of Asia and America displayed an average PR of $94.23 \%$ and $95.01 \%$, which were somewhat higher than the total group's average of $88.78 \%$. More relevant information to the question of improving future CI needs to come from the analysis of subgroups from increasing trends. There, we find five countries from the Middle East, such as Lebanon ( $\mathrm{PR}=1.593)$, Oman ( $\mathrm{PR}=1.146)$, and Iran ( $\mathrm{PR}=1.113)$, with an average PR of $120.64 \%$, and Tonga from Oceania with a PR of $120.9 \%$, which are higher than the average PR of $114.52 \%$ for the subgroup of the 44 countries with an increasing trend. 
Table 4. PRs of regional subgroups for increasing vs. decreasing trend.

\begin{tabular}{ccccccccccccc}
\hline & \multicolumn{4}{c}{ Total Group (127) } & \multicolumn{4}{c}{ Increasing Trend (44) } & \multicolumn{3}{c}{ Decreasing Trend (83) } \\
\hline Region & $\#$ & $\overline{\mathbf{X}}$ & S.D. & $\mathbf{C V}$ & $\#$ & $\overline{\mathbf{X}}$ & S.D. & $\mathbf{C V}$ & $\#$ & $\overline{\mathbf{X}}$ & S.D. & CV \\
\hline Asia & 22 & 94.23 & 18.09 & 0.19 & 9 & 110.09 & 8.26 & 0.08 & 13 & 83.25 & 14.43 & 0.17 \\
Africa & 41 & 87.69 & 27.64 & 0.32 & 14 & 116.36 & 11.45 & 0.10 & 27 & 72.83 & 20.93 & 0.29 \\
Europe & 17 & 71.34 & 11.84 & 0.17 & 0 & 0.00 & 0.00 & 0.00 & 17 & 71.34 & 11.84 & 0.17 \\
Middle East & 11 & 95.2 & 26.93 & 0.27 & 5 & 120.64 & 21.73 & 0.18 & 6 & 79.50 & 12.21 & 0.15 \\
Oceania & 5 & 73.7 & 29.8 & 0.41 & 1 & 120.90 & 0.00 & 0.00 & 4 & 61.90 & 16.22 & 0.26 \\
America & 31 & 95.01 & 19.77 & 0.21 & 15 & 113.01 & 6.34 & 0.06 & 16 & 78.14 & 15.53 & 0.20 \\
Total & 127 & 88.78 & 24.12 & 0.27 & 44 & 114.52 & 10.98 & 0.10 & 83 & 75.13 & 16.93 & 0.23 \\
\hline
\end{tabular}

The same question was examined in Table 5 for the subgroups of countries defined by three income levels. Out of 127 countries, we were able to categorize 118 countries into the three income subgroups of high, middle, and low, following the categories defined by the World Bank. Among the 41 countries with increasing trends, only the low-income subgroup with nine countries such as Bangladesh ( $P R=1.121)$, Tanzania ( $P R=1.21)$, and Haiti $(P R=1.277)$ have a higher average $P R$ of $121.03 \%$, in comparison to $114.77 \%$, which is the average PR of the 41 countries. Both the high-income subgroup with eight countries and the middle-income subgroup with 24 countries have average PRs that closely resemble the average PR for all 41 countries displaying increasing trends.

Table 5. PRs of income subgroups for increasing vs. decreasing trend.

\begin{tabular}{ccccccccccccc}
\hline & \multicolumn{4}{c}{ Total Group (118) } & \multicolumn{4}{c}{ Increasing Trend (41) } & \multicolumn{3}{c}{ Decreasing Trend (77) } \\
\hline Income & $\#$ & $\overline{\mathbf{X}}$ & S.D. & $\mathbf{C V}$ & $\#$ & $\overline{\mathbf{X}}$ & S.D. & $\mathbf{C V}$ & $\#$ & $\bar{X}$ & S.D. & CV \\
\hline High & 41 & 82.30 & 18.92 & 0.23 & 8 & 112.79 & 6.78 & 0.06 & 33 & 74.90 & 12.20 & 0.16 \\
Middle & 56 & 92.81 & 24.10 & 0.26 & 24 & 113.09 & 11.79 & 0.10 & 32 & 77.60 & 19.25 & 0.25 \\
Low & 21 & 87.48 & 33.70 & 0.39 & 9 & 121.03 & 12.00 & 0.10 & 12 & 62.32 & 18.66 & 0.30 \\
Total & 118 & 88.21 & 24.74 & 0.28 & 41 & 114.77 & 11.32 & 0.10 & 77 & 74.06 & 17.07 & 0.23 \\
\hline
\end{tabular}

\# means "Number of countries"; $\overline{\mathrm{X}}$ is "Average"; S.D. stands for "Standard deviation"; and CV is "Coefficient of variation".

\section{Conclusions}

Key findings from this research are summarized as follows. First, the average PR for the total 127 countries is $88.8 \%$, which explains a global trend of decreasing CIs. However, PRs for individual countries range widely from $24.3 \%$ to $159.3 \%$, indicating a huge variation between countries.

Second, a majority of 83 countries experienced a decreasing trend of CIs with a PR of $73.1 \%$, thus leading the world toward a rapid reduction of CI. The contribution by the United States, with a PR of $72.7 \%$, and China, with a PR of $76.2 \%$, are particularly noteworthy because these two countries represented about $43.9 \%$ of the global emissions in 2015.

Third, the most interesting finding from this research is that a large minority of 44 countries out of 127 countries, representing $34.5 \%$ of the total countries, experienced an increasing trend with an average PR of $114.5 \%$. This unexpectedly large number of countries experiencing an increasing trend of CIs has not been reported earlier, possibly because the high emitting countries were more likely to be subjected to intensive studies in the past. Additionally, many of the high emitting countries typically displayed a decreasing trend of CIs. Fourth, among those 44 countries with an increasing trend, the three regions of America, Africa, and Asia contributed to a total of 38 countries, whereas none of the countries from the European region were included. As for countries categorized by income, a total of 33 middle- and low-income countries made up the 41 countries experiencing an increasing trend of CIs. Only eight out of 41 high income countries were included. 
Fifth, on the basis of the types of experience curve, another large majority of 73 countries displayed a kinked slope with an average PR of $73.4 \%$, whereas the remaining 54 countries displayed a classical slope with an average PR of $104.2 \%$. This finding demonstrates the validity of using both kinked and classical experience curves. Sixth, among the 44 countries experiencing an increasing trend of CIs, the large majority of 35 countries displayed a classical slope, while only nine countries displayed a kinked slope.

Based on both the type of trend and slope, it is suggested that those 35 countries with a classical slope and an increasing trend of CIs have the best chances of a major improvement in their future CI trend. The remaining nine countries with an increasing trend and a kinked slope are likely to have the next best chances of a major improvement in their future trends. This will require a second kink in the future, which will generate a decreasing trend of CIs. Finally, there are 19 countries with a decreasing trend and with a classical slope. Some of these countries will also have good chances of realizing a kinked slope with a steeper decreasing trend in the future as they learn to manage their future $\mathrm{CO}_{2}$ emissions more effectively.

The contribution of this study to the literature could be twofold. First, we examined all 127 countries whose historical records are available from 1980 to 2011 . While the investigation of a relatively small number of major carbon emitting countries has produced fruitful insights, it is not clear whether we could apply the lessons to many other countries that have not been examined. Our results illustrate that there is a wide variation in terms of the CI trend among 127 countries and call for a more comprehensive approach. Second, by employing both classical and kinked EC, we clearly demonstrate that a majority of countries have displayed kinked PR with a variable rate of change during the period.

This research also bears some policy implications. First, the results allow individual countries to figure out how well they are doing in terms of CI compared to all 127 countries as well as the income and regional group peers. As this study analyzed the long-term trend of CIs of a large number of countries, some of which did not attract enough attention in the previous studies, policy makers can pinpoint their country's relative standing based on which they can develop policies for the future. Second, benchmarking the countries in the comparable group with a kinked slope would help policy makers identify the critical issues and change them to move their countries in the right direction.

There are several limitations to our study involving both conceptual and technical issues. Conceptually, the CI variable used in this study is a simplification of a complex relationship existing between carbon emissions and GDP. Many factors need to be evaluated to judge different CIs among countries, such as resource endowment, economic growth rate, energy consumption structure, international trade, and weather, to mention a few. However, in our analysis, different CIs among countries are evaluated only in terms of macro factors such as trend, slope, income, and region. In this sense, our selection should be viewed to represent the results of a first-round screening process. Technically, the model we used in this study is a simple aggregate experience curve which is driven by a single independent variable of cumulative $\mathrm{CO}_{2}$ emissions and leaves room for further refinement. For example, CIs could also be significantly influenced by the development of low-carbon energy technologies that is affected by historical events, government policies, private sector initiatives, and search behavior $[2,42,43]$. Whether a significant change in those factors has resulted in the CI slope change for the countries exhibiting a kinked slope would be an interesting issue to investigate in the future.

To conclude, our research should be viewed as a modest beginning toward better understanding the wide variation of CIs between multiple countries. It is also important to note that future studies should include countries experiencing increasing trends of Cis, like the 44 countries we have identified in this study.

Acknowledgments: We acknowledge the competent help provided by Ki Baek Kim, a research assistant at the Gachon Center of Convergence Research.

Author Contributions: Yu Sang Chang conceived the idea and analyzed the data; all authors wrote the paper.

Conflicts of Interest: The authors declare no conflict of interest. 


\section{Appendix A}

Table A1. Classical and kinked EC analyses for 127 countries.

\begin{tabular}{|c|c|c|c|c|c|c|c|c|c|c|c|c|c|}
\hline \multirow{2}{*}{ Country } & \multicolumn{4}{|c|}{ Classical Experience Equation } & \multirow{2}{*}{$\begin{array}{c}\text { Kinked } \\
\text { year }\end{array}$} & \multicolumn{7}{|c|}{ Kinked Experience Equation } & \multirow{2}{*}{$\begin{array}{c}\text { Model } \\
\text { Selection }\end{array}$} \\
\hline & $\log a$ & $b$ & $R^{2}$ & $\operatorname{PR}\left(=2^{b}\right)$ & & $\log a_{1}$ & $b_{1}$ & $\log a_{2}$ & $b_{2}$ & $b_{2}-b_{1}$ & $R^{2}$ & $\mathrm{PR}_{2}\left(=2^{b 2}\right)$ & \\
\hline 1. Zambia & $\begin{array}{l}-0.06 \\
(0.294)\end{array}$ & $\begin{array}{c}-0.398^{* *} \\
(0.078)\end{array}$ & 0.743 & 0.759 & 2004 & $\begin{array}{l}-0.344 \\
(0.204)\end{array}$ & $\begin{array}{c}-0.297^{* *} \\
(0.057)\end{array}$ & $\begin{array}{c}6.831 \\
(3.318)\end{array}$ & $\begin{array}{c}-2.043 * \\
(0.780)\end{array}$ & $\begin{array}{c}-1.746^{*} \\
(0.782)\end{array}$ & 0.886 & 0.243 & Kinked \\
\hline 2. Liberia & $\begin{array}{l}-0.014 \\
(0.079)\end{array}$ & $\begin{array}{l}-0.064 \\
(0.043)\end{array}$ & 0.01 & 0.957 & 2003 & $\begin{array}{l}-0.096 \\
(0.154)\end{array}$ & $\begin{array}{l}-0.025 \\
(0.093)\end{array}$ & $\begin{array}{l}5.403^{*} \\
(5.403)\end{array}$ & $\begin{array}{c}-1.807 * * \\
(0.509)\end{array}$ & $\begin{array}{c}-1.782 \text { ** } \\
(0.518)\end{array}$ & 0.046 & 0.286 & Kinked \\
\hline 3. Fiji & $\begin{array}{c}-0.948^{* *} \\
(0.205)\end{array}$ & $\begin{array}{c}0.049 \\
(0.076)\end{array}$ & 0.032 & 1.035 & 2003 & $\begin{array}{c}-0.709^{* *} \\
(0.186)\end{array}$ & $\begin{array}{l}-0.089 \\
(0.077)\end{array}$ & $\begin{array}{c}4.311 \\
(2.067)\end{array}$ & $\begin{array}{c}-1.375^{*} \\
(0.577)\end{array}$ & $\begin{array}{c}-1.286^{*} \\
(0.582)\end{array}$ & 0.61 & 0.386 & Kinked \\
\hline 4. Congo (Kinshasa) & $\begin{array}{l}-1.920 \text { ** } \\
(0.091)\end{array}$ & $\begin{array}{c}0.017 \\
(0.030)\end{array}$ & 0.004 & 1.012 & 1993 & $\begin{array}{c}-2.023 * * \\
(0.137)\end{array}$ & $\begin{array}{c}0.038 \\
(0.052)\end{array}$ & $\begin{array}{l}3.241 \text { ** } \\
(0.597)\end{array}$ & $\begin{array}{c}-1.159^{* *} \\
(0.136)\end{array}$ & $\begin{array}{c}-1.197^{* *} \\
(0.146)\end{array}$ & 0.673 & 0.448 & Kinked \\
\hline 5. Chad & $\begin{array}{l}-2.985^{* *} \\
(0.133)\end{array}$ & $\begin{array}{c}-0.592 * * \\
(0.092)\end{array}$ & 0.717 & 0.663 & 1992 & $\begin{array}{c}-2.999 * * \\
(0.101)\end{array}$ & $\begin{array}{l}-0.291 * \\
(0.129)\end{array}$ & $\begin{array}{c}-2.214^{* *} \\
(0.396)\end{array}$ & $\begin{array}{c}-1.106^{* *} \\
(0.237)\end{array}$ & $\begin{array}{c}-0.814^{* *} \\
(0.270)\end{array}$ & 0.806 & 0.465 & Kinked \\
\hline 6. Belize & $\begin{array}{l}-1.284^{* *} \\
(0.053)\end{array}$ & $\begin{array}{l}-0.014 \\
(0.049)\end{array}$ & 0.03 & 0.99 & 2001 & $\begin{array}{c}-1.282^{* *} \\
(0.036)\end{array}$ & $\begin{array}{l}-0.097^{*} \\
(0.040)\end{array}$ & $\begin{array}{c}1.327 \\
(0.833)\end{array}$ & $\begin{array}{l}-1.05^{*} \\
(0.371)\end{array}$ & $\begin{array}{l}-0.957^{*} \\
(0.373)\end{array}$ & 0.413 & 0.483 & Kinked \\
\hline 7. Madagascar & $\begin{array}{l}-2.369^{* * *} \\
(0.100)\end{array}$ & $\begin{array}{l}0.104 * * \\
(0.038)\end{array}$ & 0.205 & 1.075 & 2002 & $\begin{array}{c}-2.240 * * \\
(0.073)\end{array}$ & $\begin{array}{c}0.026 \\
(0.031)\end{array}$ & $\begin{array}{l}1.959^{*} \\
(0.834)\end{array}$ & $\begin{array}{c}-1.044^{* *} \\
(0.229)\end{array}$ & $\begin{array}{c}-1.070^{* *} \\
(0.231)\end{array}$ & 0.664 & 0.485 & Kinked \\
\hline 8. Dominican Republic & $\begin{array}{l}-1.352 * * \\
(0.102)\end{array}$ & $\begin{array}{c}0.030 \\
(0.023)\end{array}$ & 0.667 & 1.021 & 2003 & $\begin{array}{c}-1.558^{* *} \\
(0.073)\end{array}$ & $\begin{array}{l}0.086^{* *} \\
(0.016)\end{array}$ & $\begin{array}{l}4.429^{* *} \\
(0.946)\end{array}$ & $\begin{array}{c}-0.998^{* *} \\
(0.166)\end{array}$ & $\begin{array}{c}-1.073^{* *} \\
(0.166)\end{array}$ & 0.782 & 0.501 & Kinked \\
\hline 9. Niger & $\begin{array}{l}-2.413^{* * *} \\
(0.122)\end{array}$ & $\begin{array}{c}0.038 \\
(0.047)\end{array}$ & 0.036 & 1.027 & 2005 & $\begin{array}{l}-2.550 * * \\
(0.063)\end{array}$ & $\begin{array}{l}0.135^{* *} \\
(0.027)\end{array}$ & $\begin{array}{c}0.686 \\
(0.502)\end{array}$ & $\begin{array}{c}-0.945^{* *} \\
(0.146)\end{array}$ & $\begin{array}{c}-1.080^{* *} \\
(0.149)\end{array}$ & 0.674 & 0.519 & Kinked \\
\hline 10. Sweden & $\begin{array}{l}0.754^{* *} \\
(0.190)\end{array}$ & $\begin{array}{c}-0.314^{* *} \\
(0.029)\end{array}$ & 0.808 & 0.804 & 1994 & $\begin{array}{c}0.265 \\
(0.132)\end{array}$ & $\begin{array}{c}-0.233^{* *} \\
(0.022)\end{array}$ & $\begin{array}{l}5.364^{* *} \\
(0.459)\end{array}$ & $\begin{array}{c}-0.947^{* *} \\
(0.062)\end{array}$ & $\begin{array}{c}-0.715^{* *} \\
(0.066)\end{array}$ & 0.972 & 0.519 & Kinked \\
\hline 11. Mongolia & $\begin{array}{l}2.072^{* *} \\
(0.410)\end{array}$ & $\begin{array}{c}-0.361^{* *} \\
(0.085)\end{array}$ & 0.544 & 0.779 & 1997 & $\begin{array}{l}1.008^{* *} \\
(0.139)\end{array}$ & $\begin{array}{l}-0.055 \\
(0.038)\end{array}$ & $\begin{array}{l}4.758^{* *} \\
(0.417)\end{array}$ & $\begin{array}{c}-0.909^{* *} \\
(0.080)\end{array}$ & $\begin{array}{c}-0.854 * * \\
(0.089)\end{array}$ & 0.961 & 0.533 & Kinked \\
\hline 12. Spain & $\begin{array}{c}-0.567^{* *} \\
(0.154)\end{array}$ & $\begin{array}{c}-0.072 * * \\
(0.019)\end{array}$ & 0.487 & 0.951 & 2004 & $\begin{array}{c}-0.608^{* *} \\
(0.176)\end{array}$ & $\begin{array}{c}-0.066^{* *} \\
(0.022)\end{array}$ & $\begin{array}{l}6.273 * * \\
(1.352)\end{array}$ & $\begin{array}{c}-0.839^{* *} \\
(0.151)\end{array}$ & $\begin{array}{c}-0.077^{* *} \\
(0.152)\end{array}$ & 0.681 & 0.559 & Kinked \\
\hline 13. Austria & $\begin{array}{c}-0.559^{* * *} \\
(0.079)\end{array}$ & $\begin{array}{c}-0.107^{* *} \\
(0.013)\end{array}$ & 0.754 & 0.929 & 2003 & $\begin{array}{c}-0.644^{* *} \\
(0.056)\end{array}$ & $\begin{array}{c}-0.092 * * \\
(0.009)\end{array}$ & $\begin{array}{l}4.376^{* *} \\
(0.950)\end{array}$ & $\begin{array}{c}-0.772 * * \\
(0.128)\end{array}$ & $\begin{array}{c}-0.680^{* *} \\
(0.128)\end{array}$ & 0.895 & 0.586 & Kinked \\
\hline 14. Burundi & $\begin{array}{l}-2.907 * * \\
(0.049)\end{array}$ & $\begin{array}{l}0.238^{* *} \\
(0.050)\end{array}$ & 0.43 & 1.173 & 1994 & $\begin{array}{c}-2.927^{* *} \\
(0.050)\end{array}$ & $\begin{array}{l}0.304^{* *} \\
(0.098)\end{array}$ & $\begin{array}{l}-1.124 * \\
(0.438)\end{array}$ & $\begin{array}{c}-0.741 \text { * } \\
(0.258)\end{array}$ & $\begin{array}{c}-1.045^{* *} \\
(0.276)\end{array}$ & 0.736 & 0.598 & Kinked \\
\hline 15. Korea, North & $\begin{array}{l}2.257^{* *} \\
(0.531)\end{array}$ & $\begin{array}{c}-0.243^{* *} \\
(0.071)\end{array}$ & 0.636 & 0.845 & 1992 & $\begin{array}{l}0.977^{* *} \\
(0.194)\end{array}$ & $\begin{array}{l}-0.033 \\
(0.031)\end{array}$ & $\begin{array}{l}5.771^{* *} \\
(0.527)\end{array}$ & $\begin{array}{c}-0.703^{* *} \\
(0.068)\end{array}$ & $\begin{array}{c}-0.670^{* *} \\
(0.074)\end{array}$ & 0.944 & 0.614 & Kinked \\
\hline 16. Mauritania & $\begin{array}{l}-1.633^{* * *} \\
(0.125)\end{array}$ & $\begin{array}{l}0.246^{* *} \\
(0.051)\end{array}$ & 0.348 & 1.186 & 1992 & $\begin{array}{c}-1.699^{* *} \\
(0.093)\end{array}$ & $\begin{array}{l}0.153^{*} \\
(0.058)\end{array}$ & $\begin{array}{l}1.921^{* *} \\
(0.527)\end{array}$ & $\begin{array}{c}-0.700 \text { ** } \\
(0.147)\end{array}$ & $\begin{array}{c}-0.852^{* *} \\
(0.158)\end{array}$ & 0.864 & 0.616 & Kinked \\
\hline 17. Colombia & $\begin{array}{c}0.394 \\
(0.410)\end{array}$ & $\begin{array}{c}-0.168^{* *} \\
(0.040)\end{array}$ & 0.679 & 0.89 & 1997 & $\begin{array}{l}-0.224 \\
(0.390)\end{array}$ & $\begin{array}{l}-0.101 * \\
(0.040)\end{array}$ & $\begin{array}{l}5.982 \text { ** } \\
(0.591)\end{array}$ & $\begin{array}{c}-0.687^{* *} \\
(0.055)\end{array}$ & $\begin{array}{c}-0.586^{* *} \\
(0.068)\end{array}$ & 0.9 & 0.621 & Kinked \\
\hline 18. Denmark & $\begin{array}{l}0.709^{* *} \\
(0.248)\end{array}$ & $\begin{array}{c}-0.246^{* *} \\
(0.037)\end{array}$ & 0.689 & 0.843 & 1998 & $\begin{array}{l}-0.173 \\
(0.145)\end{array}$ & $\begin{array}{c}-0.904^{* *} \\
(0.023)\end{array}$ & $\begin{array}{l}3.850 * * \\
(0.691)\end{array}$ & $\begin{array}{c}-0.687^{* *} \\
(0.094)\end{array}$ & $\begin{array}{c}-0.596^{* *} \\
(0.097)\end{array}$ & 0.953 & 0.621 & Kinked \\
\hline 19. United Kingdom & $\begin{array}{l}1.644^{* *} \\
(0.472)\end{array}$ & $\begin{array}{l}-0.297^{* *} \\
(0.052)\end{array}$ & 0.829 & 0.814 & 1992 & $\begin{array}{c}0.317 \\
(0.226)\end{array}$ & $\begin{array}{l}-0.128^{* *} \\
(0.027)\end{array}$ & $\begin{array}{l}5.193^{* *} \\
(0.243)\end{array}$ & $\begin{array}{c}-0.674^{* *} \\
(0.026)\end{array}$ & $\begin{array}{l}-0.546^{* *} \\
(0.037)\end{array}$ & 0.993 & 0.627 & Kinked \\
\hline 20. Jordan & $\begin{array}{c}-0.434^{* *} \\
(0.142)\end{array}$ & $\begin{array}{c}0.049 \\
(0.031)\end{array}$ & 0.119 & 1.035 & 2000 & $\begin{array}{c}-0.814^{* *} \\
(0.075)\end{array}$ & $\begin{array}{l}0.152^{* *} \\
(0.017)\end{array}$ & $\begin{array}{l}3.502 * * \\
(0.596)\end{array}$ & $\begin{array}{c}-0.651^{* *} \\
(0.104)\end{array}$ & $\begin{array}{c}-0.803 * * \\
(0.106)\end{array}$ & 0.898 & 0.637 & Kinked \\
\hline
\end{tabular}


Table A1. Cont.

\begin{tabular}{|c|c|c|c|c|c|c|c|c|c|c|c|c|c|}
\hline \multirow{2}{*}{ Country } & \multicolumn{4}{|c|}{ Classical Experience Equation } & \multirow{2}{*}{$\begin{array}{c}\text { Kinked } \\
\text { year }\end{array}$} & \multicolumn{7}{|c|}{ Kinked Experience Equation } & \multirow{2}{*}{$\begin{array}{c}\text { Model } \\
\text { Selection }\end{array}$} \\
\hline & $\log a$ & $b$ & $R^{2}$ & $\operatorname{PR}\left(=2^{b}\right)$ & & $\log a_{1}$ & $b_{1}$ & $\log a_{2}$ & $b_{2}$ & $b_{2}-b_{1}$ & $R^{2}$ & $\mathrm{PR}_{2}\left(=2^{b 2}\right)$ & \\
\hline 21. Mozambique & $\begin{array}{c}0.317 \\
(0.361)\end{array}$ & $\begin{array}{c}-0.581 \text { ** } \\
(0.106)\end{array}$ & 0.791 & 0.669 & 1986 & $\begin{array}{c}-0.745^{* *} \\
(0.237)\end{array}$ & $\begin{array}{c}0.01 \\
(0.110)\end{array}$ & $\begin{array}{c}0.433 \\
(0.331)\end{array}$ & $\begin{array}{c}-0.623^{* *} \\
(0.096)\end{array}$ & $\begin{array}{c}-0.633^{* *} \\
(0.146)\end{array}$ & 0.909 & 0.649 & Kinked \\
\hline 22. New Zealand & $\begin{array}{c}-0.995^{* *} \\
(0.107)\end{array}$ & $\begin{array}{c}0.010 \\
(0.019)\end{array}$ & 0.011 & 1.007 & 2006 & $\begin{array}{c}-1.207^{* *} \\
(0.080)\end{array}$ & $\begin{array}{l}0.054^{* *} \\
(0.014)\end{array}$ & $\begin{array}{c}3.198^{* * * *} \\
(0.539)\end{array}$ & $\begin{array}{c}-0.624^{* *} \\
(0.078)\end{array}$ & $\begin{array}{c}-0.678^{* *} \\
(0.079)\end{array}$ & 0.631 & 0.649 & Kinked \\
\hline 23. Iraq & $\begin{array}{c}-2.649^{* *} \\
(0.369)\end{array}$ & $\begin{array}{l}0.296^{* *} \\
(0.055)\end{array}$ & 0.341 & 1.228 & 1990 & $\begin{array}{c}-3.462 * * \\
(0.545)\end{array}$ & $\begin{array}{l}0.418^{* *} \\
(0.099)\end{array}$ & $\begin{array}{l}3.896^{* *} \\
(0.859)\end{array}$ & $\begin{array}{c}-0.614^{* *} \\
(0.117)\end{array}$ & $\begin{array}{c}-1.032 * * \\
(0.153)\end{array}$ & 0.804 & 0.653 & Kinked \\
\hline 24. Venezuela & $\begin{array}{c}-0.511 \text { ** } \\
(0.120)\end{array}$ & $\begin{array}{l}-0.01 \\
(0.017)\end{array}$ & 0.013 & 0.993 & 2001 & $\begin{array}{c}-0.603 \text { ** } \\
(0.110)\end{array}$ & $\begin{array}{c}0.004 \\
(0.016)\end{array}$ & $\begin{array}{l}4.262^{*} \\
(1.512)\end{array}$ & $\begin{array}{c}-0.601 * \\
(0.188)\end{array}$ & $\begin{array}{c}-0.605 \text { ** } \\
(0.189)\end{array}$ & 0.47 & 0.659 & Kinked \\
\hline 25. Portugal & $\begin{array}{c}-1.795^{* *} \\
(0.121)\end{array}$ & $\begin{array}{l}0.075^{* *} \\
(0.020)\end{array}$ & 0.456 & 1.053 & 2006 & $\begin{array}{c}-2.0011^{* *} \\
(0.103)\end{array}$ & $\begin{array}{l}0.116^{* *} \\
(0.017)\end{array}$ & $\begin{array}{c}2.873 \\
(1.110)\end{array}$ & $\begin{array}{c}-0.589^{*} \\
(0.154)\end{array}$ & $\begin{array}{c}-0.704^{* *} \\
(0.155)\end{array}$ & 0.859 & 0.665 & Kinked \\
\hline 26. Switzerland & $\begin{array}{c}-0.847 \text { ** } \\
(0.111)\end{array}$ & $\begin{array}{c}-0.134^{* *} \\
(0.018)\end{array}$ & 0.742 & 0.911 & 2000 & $\begin{array}{c}-1.1311^{* *} \\
(0.152)\end{array}$ & $\begin{array}{c}-0.813^{* *} \\
(0.025)\end{array}$ & $\begin{array}{l}2.136^{* *} \\
(0.625)\end{array}$ & $\begin{array}{c}-0.563 \text { ** } \\
(0.089)\end{array}$ & $\begin{array}{c}-0.481 \text { ** } \\
(0.093)\end{array}$ & 0.929 & 0.677 & Kinked \\
\hline 27. Cameroon & $\begin{array}{c}-2.433^{* *} \\
(0.256)\end{array}$ & $\begin{array}{c}0.108 \\
(0.054)\end{array}$ & 0.15 & 1.078 & 1993 & $\begin{array}{c}-2.537^{* *} \\
(0.279)\end{array}$ & $\begin{array}{c}0.13 \\
(0.086)\end{array}$ & $\begin{array}{c}0.847 \\
(0.421)\end{array}$ & $\begin{array}{c}-0.560 * * \\
(0.087)\end{array}$ & $\begin{array}{c}-0.690 * * \\
(0.122)\end{array}$ & 0.407 & 0.678 & Kinked \\
\hline 28. Finland & $\begin{array}{l}0.398^{* *} \\
(0.122)\end{array}$ & $\begin{array}{c}-0.191 \text { ** } \\
(0.020)\end{array}$ & 0.692 & 0.876 & 1993 & $\begin{array}{c}0.041 \\
(0.196)\end{array}$ & $\begin{array}{c}-0.129^{* *} \\
(0.033)\end{array}$ & $\begin{array}{l}2.961^{* *} \\
(0.459)\end{array}$ & $\begin{array}{c}-0.555^{* *} \\
(0.065)\end{array}$ & $\begin{array}{c}-0.426^{* *} \\
(0.073)\end{array}$ & 0.86 & 0.681 & Kinked \\
\hline 29. Vanuatu & $\begin{array}{c}-1.838^{* *} \\
(0.050)\end{array}$ & $\begin{array}{l}-0.337^{* *} \\
(0.046)\end{array}$ & 0.525 & 0.792 & 1986 & $\begin{array}{c}-1.677^{* *} \\
(0.077)\end{array}$ & $\begin{array}{l}-0.157^{*} \\
(0.070)\end{array}$ & $\begin{array}{l}-1.701^{* *} \\
(0.117)\end{array}$ & $\begin{array}{c}-0.554^{* *} \\
(0.149)\end{array}$ & $\begin{array}{c}-0.397 * \\
(0.165)\end{array}$ & 0.582 & 0.681 & Kinked \\
\hline 30. Greece & $\begin{array}{c}-1.266^{* *} \\
(0.168)\end{array}$ & $\begin{array}{c}0.048 \\
(0.025)\end{array}$ & 0.133 & 1.034 & 1999 & $\begin{array}{c}-1.853^{* *} \\
(0.137)\end{array}$ & $\begin{array}{l}0.150^{* *} \\
(0.021)\end{array}$ & $\begin{array}{l}3.249^{* *} \\
(0.420)\end{array}$ & $\begin{array}{c}-0.553^{* *} \\
(0.055)\end{array}$ & $\begin{array}{c}-0.703^{* *} \\
(0.059)\end{array}$ & 0.94 & 0.682 & Kinked \\
\hline 31. Argentina & $\begin{array}{c}-1.105^{* *} \\
(0.185)\end{array}$ & $\begin{array}{l}-0.022 \\
(0.025)\end{array}$ & 0.069 & 0.984 & 1991 & $\begin{array}{c}-1.815^{* *} \\
(0.098)\end{array}$ & $\begin{array}{l}0.098^{* *} \\
(0.016)\end{array}$ & $\begin{array}{l}-0.497 \\
(0.247)\end{array}$ & $\begin{array}{c}-0.102 * * \\
(0.032)\end{array}$ & $\begin{array}{c}-0.120 \text { ** } \\
(0.036)\end{array}$ & 0.699 & 0.709 & Kinked \\
\hline 32. Israel & $\begin{array}{c}-0.958^{* *} \\
(0.063)\end{array}$ & $\begin{array}{c}0.009 \\
(0.012)\end{array}$ & 0.018 & 1.006 & 2001 & $\begin{array}{c}-1.087^{* *} \\
(0.042)\end{array}$ & $\begin{array}{l}0.034^{* *} \\
(0.008)\end{array}$ & $\begin{array}{l}2.607^{* *} \\
(0.316)\end{array}$ & $\begin{array}{c}-0.496^{* *} \\
(0.045)\end{array}$ & $\begin{array}{c}-0.530 * * \\
(0.046)\end{array}$ & 0.749 & 0.709 & Kinked \\
\hline 33. Ireland & $\begin{array}{c}0.055 \\
(0.182)\end{array}$ & $\begin{array}{c}-0.188^{* *} \\
(0.030)\end{array}$ & 0.716 & 0.878 & 1994 & $\begin{array}{c}-0.6311^{* *} \\
(0.108)\end{array}$ & $\begin{array}{l}-0.041 \\
(0.021)\end{array}$ & $\begin{array}{l}1.976^{* *} \\
(0.136)\end{array}$ & $\begin{array}{c}-0.488^{* *} \\
(0.022)\end{array}$ & $\begin{array}{c}-0.4477^{* *} \\
(0.030)\end{array}$ & 0.964 & 0.713 & Kinked \\
\hline 34. Canada & $\begin{array}{l}0.737^{* *} \\
(0.148)\end{array}$ & $\begin{array}{c}-0.147^{* *} \\
(0.017)\end{array}$ & 0.804 & 0.903 & 1997 & $\begin{array}{l}0.295^{* *} \\
(0.041)\end{array}$ & $\begin{array}{c}-0.090^{* *} \\
(0.005)\end{array}$ & $\begin{array}{l}3.885^{* *} \\
(0.236)\end{array}$ & $\begin{array}{c}-0.483^{* *} \\
(0.025)\end{array}$ & $\begin{array}{c}-0.393 \text { ** } \\
(0.026)\end{array}$ & 0.975 & 0.715 & Kinked \\
\hline 35. Botswana & $\begin{array}{c}-0.705^{* *} \\
(0.066)\end{array}$ & $\begin{array}{c}-0.150^{* *} \\
(0.019)\end{array}$ & 0.607 & 0.901 & 1992 & $\begin{array}{c}-0.873^{* *} \\
(0.114)\end{array}$ & $\begin{array}{l}-0.076 \\
(0.048)\end{array}$ & $\begin{array}{l}0.572^{* *} \\
(0.130)\end{array}$ & $\begin{array}{c}-0.466^{* *} \\
(0.034)\end{array}$ & $\begin{array}{c}-0.391 \text { ** } \\
(0.059)\end{array}$ & 0.869 & 0.724 & Kinked \\
\hline 36. United States & $\begin{array}{l}1.560^{* * *} \\
(0.263)\end{array}$ & $\begin{array}{c}-0.196^{* *} \\
(0.024)\end{array}$ & 0.882 & 0.873 & 1996 & $\begin{array}{c}0.852^{* * *} \\
(0.098)\end{array}$ & $\begin{array}{c}-0.1211^{* *} \\
(0.009)\end{array}$ & $\begin{array}{l}4.665^{* *} \\
(0.185)\end{array}$ & $\begin{array}{c}-0.459 \text { ** } \\
(0.016)\end{array}$ & $\begin{array}{c}-0.338^{* *} \\
(0.018)\end{array}$ & 0.995 & 0.727 & Kinked \\
\hline 37. Equatorial Guinea & $\begin{array}{c}-1.812 \text { ** } \\
(0.120)\end{array}$ & $\begin{array}{l}0.195^{* *} \\
(0.041)\end{array}$ & 0.278 & 1.145 & 1997 & $\begin{array}{c}-1.494^{* *} \\
(0.146)\end{array}$ & $\begin{array}{l}0.665 * * \\
(0.114)\end{array}$ & $\begin{array}{c}0.135 \\
(0.160)\end{array}$ & $\begin{array}{c}-0.455^{* *} \\
(0.042)\end{array}$ & $\begin{array}{c}-1.120 * * \\
(0.150)\end{array}$ & 0.765 & 0.73 & Kinked \\
\hline 38. Luxembourg & $\begin{array}{l}1.548^{* *} \\
(0.244)\end{array}$ & $\begin{array}{c}-0.450 * * \\
(0.048)\end{array}$ & 0.885 & 0.732 & 1995 & $\begin{array}{l}0.870^{* * *} \\
(0.089)\end{array}$ & $\begin{array}{c}-0.268^{* *} \\
(0.020)\end{array}$ & $\begin{array}{c}0.753 \\
(0.513)\end{array}$ & $\begin{array}{c}-0.317^{* *} \\
(0.092)\end{array}$ & $\begin{array}{l}-0.049 \\
(0.094)\end{array}$ & 0.975 & 0.803 & Classical \\
\hline 39. Central African Republic & $\begin{array}{c}-2.701^{* *} \\
(0.053)\end{array}$ & $\begin{array}{c}0.05 \\
(0.041)\end{array}$ & 0.106 & 1.035 & 1993 & $\begin{array}{c}-2.704^{* *} \\
(0.024)\end{array}$ & $\begin{array}{l}0.158^{* * *} \\
(0.029)\end{array}$ & $\begin{array}{c}-1.863^{* *} \\
(0.062)\end{array}$ & $\begin{array}{c}-0.437^{* *} \\
(0.038)\end{array}$ & $\begin{array}{c}-0.595^{* *} \\
(0.048)\end{array}$ & 0.854 & 0.739 & Kinked \\
\hline 40. Guinea & $\begin{array}{c}-2.552^{* *} \\
(0.103)\end{array}$ & $\begin{array}{c}-0.127 * * \\
(0.035)\end{array}$ & 0.429 & 0.916 & 1994 & $\begin{array}{c}-2.790 * * \\
(0.054)\end{array}$ & $\begin{array}{c}0.05 \\
(0.033)\end{array}$ & $\begin{array}{c}-1.673^{* *} \\
(0.110)\end{array}$ & $\begin{array}{c}-0.412 * * \\
(0.034)\end{array}$ & $\begin{array}{c}-0.4622^{* *} \\
(0.047)\end{array}$ & 0.858 & 0.752 & Kinked \\
\hline 41. Belgium & $\begin{array}{l}0.495^{* *} \\
(0.133)\end{array}$ & $\begin{array}{c}-0.159^{* *} \\
(0.018)\end{array}$ & 0.839 & 0.896 & 1994 & $\begin{array}{c}0.345 \\
(0.183)\end{array}$ & $\begin{array}{c}-0.138^{* *} \\
(0.026)\end{array}$ & $\begin{array}{l}2.418^{* *} \\
(0.305)\end{array}$ & $\begin{array}{c}-0.399 * * \\
(0.038)\end{array}$ & $\begin{array}{l}-0.2611^{* *} \\
(0.047)\end{array}$ & 0.945 & 0.758 & Kinked \\
\hline 42. Australia & $\begin{array}{l}-0.01 \\
(0.128)\end{array}$ & $\begin{array}{c}-0.058^{* *} \\
(0.015)\end{array}$ & 0.647 & 0.961 & 2006 & $\begin{array}{l}-0.12 \\
(0.114)\end{array}$ & $\begin{array}{c}-0.042 * * \\
(0.014)\end{array}$ & $\begin{array}{l}3.026^{* *} \\
(0.608)\end{array}$ & $\begin{array}{c}-0.396^{* *} \\
(0.067)\end{array}$ & $\begin{array}{c}-0.353^{* *} \\
(0.069)\end{array}$ & 0.8 & 0.76 & Kinked \\
\hline 43. China & $\begin{array}{l}4.085^{* *} \\
(0.433)\end{array}$ & $\begin{array}{c}-0.373 \text { ** } \\
(0.041)\end{array}$ & 0.907 & 0.772 & 1993 & $\begin{array}{l}2.527 \text { *** } \\
(0.337)\end{array}$ & $\begin{array}{c}-0.195^{* *} \\
(0.036)\end{array}$ & $\begin{array}{l}4.255^{* *} \\
(0.583)\end{array}$ & $\begin{array}{c}-0.392 \text { ** } \\
(0.053)\end{array}$ & $\begin{array}{c}-0.197^{* *} \\
(0.064)\end{array}$ & 0.974 & 0.762 & Kinked \\
\hline
\end{tabular}


Table A1. Cont.

\begin{tabular}{|c|c|c|c|c|c|c|c|c|c|c|c|c|c|}
\hline \multirow{2}{*}{ Country } & \multicolumn{4}{|c|}{ Classical Experience Equation } & \multirow{2}{*}{$\begin{array}{c}\text { Kinked } \\
\text { year }\end{array}$} & \multicolumn{7}{|c|}{ Kinked Experience Equation } & \multirow{2}{*}{$\begin{array}{c}\text { Model } \\
\text { Selection }\end{array}$} \\
\hline & $\log a$ & $b$ & $R^{2}$ & $\operatorname{PR}\left(=2^{b}\right)$ & & $\log a_{1}$ & $b_{1}$ & $\log a_{2}$ & $b_{2}$ & $b_{2}-b_{1}$ & $R^{2}$ & $\mathrm{PR}_{2}\left(=2^{b 2}\right)$ & \\
\hline 44. France & $\begin{array}{l}0.702 * * \\
(0.095)\end{array}$ & $\begin{array}{c}-0.243 * * \\
(0.011)\end{array}$ & 0.962 & 0.845 & 1996 & $\begin{array}{l}0.713^{* *} \\
(0.172)\end{array}$ & $\begin{array}{c}-0.245 * * \\
(0.021)\end{array}$ & $\begin{array}{l}2.055^{* *} \\
(0.348)\end{array}$ & $\begin{array}{c}-0.390^{* *} \\
(0.038)\end{array}$ & $\begin{array}{c}-0.145^{* *} \\
(0.044)\end{array}$ & 0.974 & 0.763 & Kinked \\
\hline 45. Pakistan & $\begin{array}{c}-1.379^{* *} \\
(0.053)\end{array}$ & $\begin{array}{c}0.011 \\
(0.009)\end{array}$ & 0.041 & 1.008 & 2007 & $\begin{array}{c}-1.460^{* *} \\
(0.058)\end{array}$ & $\begin{array}{l}0.025^{*} \\
(0.010)\end{array}$ & $\begin{array}{c}1.204 \\
(0.451)\end{array}$ & $\begin{array}{c}-0.327^{*} \\
(0.058)\end{array}$ & $\begin{array}{c}-0.352 \text { ** } \\
(0.059)\end{array}$ & 0.306 & 0.797 & Kinked \\
\hline 46. Nepal & $\begin{array}{c}-3.046^{* *} \\
(0.091)\end{array}$ & $\begin{array}{l}0.235^{* *} \\
(0.031)\end{array}$ & 0.709 & 1.177 & 1998 & $\begin{array}{c}-2.992 * * \\
(0.107)\end{array}$ & $\begin{array}{l}0.163^{*} \\
(0.059)\end{array}$ & $\begin{array}{c}-0.9744^{* *} \\
(0.260)\end{array}$ & $\begin{array}{c}-0.320^{* *} \\
(0.072)\end{array}$ & $\begin{array}{c}-0.483^{* *} \\
(0.093)\end{array}$ & 0.884 & 0.801 & Kinked \\
\hline 47. Swaziland & $\begin{array}{c}-1.383^{* *} \\
(0.043)\end{array}$ & $\begin{array}{c}-0.275^{* *} \\
(0.017)\end{array}$ & 0.82 & 0.826 & 1990 & $\begin{array}{c}-1.390^{* *} \\
(0.046)\end{array}$ & $\begin{array}{l}-0.244^{* *} \\
(0.033)\end{array}$ & $\begin{array}{c}-1.677^{* *} \\
(0.222)\end{array}$ & $\begin{array}{c}-0.173^{*} \\
(0.075)\end{array}$ & $\begin{array}{c}0.071 \\
(0.082)\end{array}$ & 0.841 & 0.887 & Classical \\
\hline 48. Saudi Arabia & $\begin{array}{c}-0.448^{*} \\
(0.194)\end{array}$ & $\begin{array}{c}0.028 \\
(0.032)\end{array}$ & 0.038 & 1.02 & 1993 & $\begin{array}{c}-1.245^{* *} \\
(0.290)\end{array}$ & $\begin{array}{l}0.204^{* *} \\
(0.058)\end{array}$ & $\begin{array}{l}1.521 * * \\
(0.224)\end{array}$ & $\begin{array}{c}-0.274^{* *} \\
(0.034)\end{array}$ & $\begin{array}{c}-0.477^{* *} \\
(0.068)\end{array}$ & 0.77 & 0.827 & Kinked \\
\hline 49. French Guiana & $\begin{array}{c}-0.592 * * \\
(0.048)\end{array}$ & $\begin{array}{c}-0.072 \text { ** } \\
(0.022)\end{array}$ & 0.242 & 0.845 & 1993 & $\begin{array}{c}-0.608^{* *} \\
(0.043)\end{array}$ & $\begin{array}{c}-0.1155^{* *} \\
(0.035)\end{array}$ & $\begin{array}{c}0.262 \\
(0.189)\end{array}$ & $\begin{array}{c}-0.377^{* *} \\
(0.069)\end{array}$ & $\begin{array}{c}-0.262 \text { ** } \\
(0.078)\end{array}$ & 0.622 & 0.834 & Kinked \\
\hline 50. Syria & $\begin{array}{c}-0.448 \text { * } \\
(0.194)\end{array}$ & $\begin{array}{c}0.028 \\
(0.032)\end{array}$ & 0.038 & 1.02 & 1989 & $\begin{array}{c}-1.134 * * \\
(0.371)\end{array}$ & $\begin{array}{l}0.174^{*} \\
(0.079)\end{array}$ & $\begin{array}{l}1.387^{* *} \\
(0.206)\end{array}$ & $\begin{array}{c}-0.254^{* *} \\
(0.032)\end{array}$ & $\begin{array}{c}-0.428^{* *} \\
(0.085)\end{array}$ & 0.816 & 0.839 & Kinked \\
\hline 51. Mali & $\begin{array}{c}-2.722^{* * *} \\
(0.103)\end{array}$ & $\begin{array}{c}-0.243^{* *} \\
(0.046)\end{array}$ & 0.645 & 0.845 & 1989 & $\begin{array}{c}-2.754^{* *} \\
(0.267)\end{array}$ & $\begin{array}{l}-0.297 \\
(0.317)\end{array}$ & $\begin{array}{c}-2.288^{* *} \\
(0.071)\end{array}$ & $\begin{array}{c}-0.425^{* *} \\
(0.031)\end{array}$ & $\begin{array}{l}-0.128 \\
(0.319)\end{array}$ & 0.731 & 0.745 & Classical \\
\hline 52. Puerto Rico & $\begin{array}{l}0.484^{* *} \\
(0.156)\end{array}$ & $\begin{array}{c}-0.237^{* *} \\
(0.027)\end{array}$ & 0.763 & 0.849 & 2001 & $\begin{array}{l}0.926^{* *} \\
(0.305)\end{array}$ & $\begin{array}{c}-0.327^{* *} \\
(0.054)\end{array}$ & $\begin{array}{c}1.977 \\
(1.305)\end{array}$ & $\begin{array}{c}-0.452^{*} \\
(0.198)\end{array}$ & $\begin{array}{l}-0.124 \\
(0.205)\end{array}$ & 0.898 & 0.731 & Classical \\
\hline 53. Bermuda & $\begin{array}{c}-1.130^{* *} \\
(0.095)\end{array}$ & $\begin{array}{c}-0.134^{* *} \\
(0.039)\end{array}$ & 0.319 & 0.911 & 1992 & $\begin{array}{c}-1.303^{* *} \\
(0.124)\end{array}$ & $\begin{array}{c}0.145 \\
(0.108)\end{array}$ & $\begin{array}{c}-0.928^{* *} \\
(0.192)\end{array}$ & $\begin{array}{c}-0.235^{* *} \\
(0.078)\end{array}$ & $\begin{array}{c}-0.379 * * \\
(0.133)\end{array}$ & 0.768 & 0.85 & Kinked \\
\hline 54. Morocco & $\begin{array}{c}-1.492 * * \\
(0.050)\end{array}$ & $\begin{array}{l}-0.015 \\
(0.010)\end{array}$ & 0.042 & 0.99 & 1993 & $\begin{array}{c}-1.457^{* *} \\
(0.041)\end{array}$ & $\begin{array}{c}-0.028^{* *} \\
(0.009)\end{array}$ & $\begin{array}{l}-0.203 \\
(0.214)\end{array}$ & $\begin{array}{c}-0.217^{* *} \\
(0.035)\end{array}$ & $\begin{array}{c}-0.189 * * \\
(0.036)\end{array}$ & 0.703 & 0.86 & Kinked \\
\hline 55. Norway & $\begin{array}{c}-0.690^{* *} \\
(0.100)\end{array}$ & $\begin{array}{c}-0.133 \text { ** } \\
(0.016)\end{array}$ & 0.775 & 0.912 & 1985 & $\begin{array}{c}-0.807^{* *} \\
(0.098)\end{array}$ & $\begin{array}{c}-0.120^{* *} \\
(0.023)\end{array}$ & $\begin{array}{l}-0.166 \\
(0.122)\end{array}$ & $\begin{array}{c}-0.213^{* *} \\
(0.020)\end{array}$ & $\begin{array}{c}-0.093 \text { ** } \\
(0.030)\end{array}$ & 0.896 & 0.863 & Kinked \\
\hline 56. Angola & $\begin{array}{c}-2.531 \text { ** } \\
(0.146)\end{array}$ & $\begin{array}{l}0.272 * * \\
(0.035)\end{array}$ & 0.611 & 1.207 & 1993 & $\begin{array}{c}-2.358^{* *} \\
(0.203)\end{array}$ & $\begin{array}{l}0.181^{*} \\
(0.069)\end{array}$ & $\begin{array}{c}0.061 \\
(0.492)\end{array}$ & $\begin{array}{c}-0.209^{*} \\
(0.092)\end{array}$ & $\begin{array}{c}-0.390 * * \\
(0.115)\end{array}$ & 0.881 & 0.865 & Kinked \\
\hline 57. Bahrain & $\begin{array}{l}0.853^{* *} \\
(0.166)\end{array}$ & $\begin{array}{c}-0.071^{*} \\
(0.030)\end{array}$ & 0.359 & 0.952 & 1985 & $\begin{array}{c}0.453 \\
(0.311)\end{array}$ & $\begin{array}{c}0.027 \\
(0.099)\end{array}$ & $\begin{array}{l}1.481^{* *} \\
(0.126)\end{array}$ & $\begin{array}{c}-0.183^{* *} \\
(0.021)\end{array}$ & $\begin{array}{c}-0.210^{*} \\
(0.102)\end{array}$ & 0.783 & 0.881 & Kinked \\
\hline 58. Netherlands Antilles & $\begin{array}{l}2.085^{* *} \\
(0.088)\end{array}$ & $\begin{array}{c}-0.180^{* *} \\
(0.017)\end{array}$ & 0.702 & 0.883 & 1995 & $\begin{array}{l}2.563^{* * *} \\
(0.318)\end{array}$ & $\begin{array}{c}-0.298^{* *} \\
(0.069)\end{array}$ & $\begin{array}{l}1.884^{* *} \\
(0.383)\end{array}$ & $\begin{array}{l}-0.138 \\
(0.069)\end{array}$ & $\begin{array}{c}0.16 \\
(0.097)\end{array}$ & 0.865 & 0.909 & Classical \\
\hline 59. Gabon & $\begin{array}{l}-0.019 \\
(0.184)\end{array}$ & $\begin{array}{c}-0.172 * * \\
(0.042)\end{array}$ & 0.572 & 0.888 & 2006 & $\begin{array}{l}-0.194 \\
(0.138)\end{array}$ & $\begin{array}{c}-0.118 \text { ** } \\
(0.033)\end{array}$ & $\begin{array}{l}-1.469 \\
(2.771)\end{array}$ & $\begin{array}{c}0.086 \\
(0.555)\end{array}$ & $\begin{array}{c}0.204 \\
(0.556)\end{array}$ & 0.771 & 1.061 & Classical \\
\hline 60. Somalia & $\begin{array}{c}-1.047^{* *} \\
(0.173)\end{array}$ & $\begin{array}{c}-0.166^{*} \\
(0.061)\end{array}$ & 0.39 & 0.891 & 1991 & $\begin{array}{c}-1.197^{* *} \\
(0.161)\end{array}$ & $\begin{array}{l}-0.032 \\
(0.082)\end{array}$ & $\begin{array}{c}-2.371^{* *} \\
(0.420)\end{array}$ & $\begin{array}{c}0.261 \\
(0.139)\end{array}$ & $\begin{array}{c}0.293 \\
(0.161)\end{array}$ & 0.733 & 1.198 & Classical \\
\hline 61. Cyprus & $\begin{array}{c}-0.771 \text { ** } \\
(0.065)\end{array}$ & $\begin{array}{c}0.007 \\
(0.015)\end{array}$ & 0.012 & 1.005 & 1992 & $\begin{array}{c}-0.857^{* *} \\
(0.189)\end{array}$ & $\begin{array}{c}0.032 \\
(0.061)\end{array}$ & $\begin{array}{c}0.025 \\
(0.114)\end{array}$ & $\begin{array}{c}-0.160^{* *} \\
(0.024)\end{array}$ & $\begin{array}{c}-0.192 * * \\
(0.065)\end{array}$ & 0.601 & 0.895 & Kinked \\
\hline 62. Reunion & $\begin{array}{c}-1.592 * * \\
(0.048)\end{array}$ & $\begin{array}{l}0.207^{* *} \\
(0.019)\end{array}$ & 0.738 & 1.154 & 1993 & $\begin{array}{c}-1.676^{* *} \\
(0.086)\end{array}$ & $\begin{array}{l}0.240 * * \\
(0.052)\end{array}$ & $\begin{array}{l}-0.302 * \\
(0.108)\end{array}$ & $\begin{array}{c}-0.158^{* *} \\
(0.029)\end{array}$ & $\begin{array}{c}-0.397 \text { ** } \\
(0.060)\end{array}$ & 0.933 & 0.896 & Kinked \\
\hline 63. Netherlands & $\begin{array}{l}0.453^{*} \\
(0.179)\end{array}$ & $\begin{array}{c}-0.147^{* *} \\
(0.023)\end{array}$ & 747 & 0.903 & 2005 & $\begin{array}{c}0.127 \\
(0.079)\end{array}$ & $\begin{array}{c}-0.100 * * \\
(0.010)\end{array}$ & $\begin{array}{c}4.565 \\
(3.420)\end{array}$ & $\begin{array}{l}-0.628 \\
(0.390)\end{array}$ & $\begin{array}{l}-0.527 \\
(0.390)\end{array}$ & 0.941 & 0.647 & Classical \\
\hline 64. India & $\begin{array}{l}-0.406 \\
(0.209)\end{array}$ & $\begin{array}{l}-0.026 \\
(0.023)\end{array}$ & 0.095 & 0.982 & 2003 & $\begin{array}{c}-0.855^{* *} \\
(0.126)\end{array}$ & $\begin{array}{l}0.032 * \\
(0.015)\end{array}$ & $\begin{array}{c}0.706 \\
(0.535)\end{array}$ & $\begin{array}{l}-0.148^{*} \\
(0.054)\end{array}$ & $\begin{array}{c}-0.180 * * \\
(0.056)\end{array}$ & 0.779 & 0.903 & Kinked \\
\hline 65. Costa Rica & $\begin{array}{c}-2.088^{* *} \\
(0.054)\end{array}$ & $\begin{array}{c}0.022 \\
(0.014)\end{array}$ & 0.059 & 1.015 & 1992 & $\begin{array}{c}-2.022 \text { ** } \\
(0.044)\end{array}$ & $\begin{array}{l}-0.022 \\
(0.019)\end{array}$ & $\begin{array}{c}-1.352^{* *} \\
(0.141)\end{array}$ & $\begin{array}{c}-0.144^{* *} \\
(0.033)\end{array}$ & $\begin{array}{c}-0.122 \text { ** } \\
(0.038)\end{array}$ & 0.602 & 0.905 & Kinked \\
\hline
\end{tabular}


Table A1. Cont.

\begin{tabular}{|c|c|c|c|c|c|c|c|c|c|c|c|c|c|}
\hline \multirow{2}{*}{ Country } & \multicolumn{4}{|c|}{ Classical Experience Equation } & \multirow{2}{*}{$\begin{array}{c}\text { Kinked } \\
\text { year }\end{array}$} & \multicolumn{7}{|c|}{ Kinked Experience Equation } & \multirow{2}{*}{$\begin{array}{c}\text { Model } \\
\text { Selection }\end{array}$} \\
\hline & $\log a$ & $b$ & $R^{2}$ & $\operatorname{PR}\left(=2^{b}\right)$ & & $\log a_{1}$ & $b_{1}$ & $\log a_{2}$ & $b_{2}$ & $b_{2}-b_{1}$ & $R^{2}$ & $\mathrm{PR}_{2}\left(=2^{b 2}\right)$ & \\
\hline 66. Peru & $\begin{array}{c}-1.141^{* *} \\
(0.186)\end{array}$ & $\begin{array}{c}-0.088^{* *} \\
(0.031)\end{array}$ & 0.564 & 0.941 & 1982 & $\begin{array}{c}-1.535^{* *} \\
(0.158)\end{array}$ & $\begin{array}{l}-0.015 \\
(0.049)\end{array}$ & $\begin{array}{c}-0.810^{* *} \\
(0.076)\end{array}$ & $\begin{array}{c}-0.143^{* *} \\
(0.013)\end{array}$ & $\begin{array}{l}-0.128^{*} \\
(0.051)\end{array}$ & 0.816 & 0.906 & Kinked \\
\hline 67. Antigua and Barbuda & $\begin{array}{c}-0.620^{* *} \\
(0.083)\end{array}$ & $\begin{array}{c}-0.138^{* *} \\
(0.041)\end{array}$ & 0.468 & 0.909 & 1983 & $\begin{array}{l}-0.313 \\
(0.259)\end{array}$ & $\begin{array}{c}0.102 \\
(0.601)\end{array}$ & $\begin{array}{c}-0.847^{* *} \\
(0.051)\end{array}$ & $\begin{array}{l}-0.029 \\
(0.029)\end{array}$ & $\begin{array}{l}-0.131 \\
(0.602)\end{array}$ & 0.8137 & 1.073 & Classical \\
\hline 68. Lesotho & $\begin{array}{c}-2.629^{* *} \\
(0.030)\end{array}$ & $\begin{array}{c}-0.128^{* *} \\
(0.044)\end{array}$ & 0.267 & 0.915 & 2010 & $\begin{array}{c}-2.632 * * \\
(0.036)\end{array}$ & $\begin{array}{l}-0.18^{* *} \\
(0.029)\end{array}$ & 3.565 & -3.203 & $\begin{array}{l}-3.016 \\
(87.590)\end{array}$ & 0.801 & 0.109 & Classical \\
\hline 69. Mexico & $\begin{array}{c}-0.716^{* *} \\
(0.158)\end{array}$ & $\begin{array}{c}-0.049 * \\
(0.019)\end{array}$ & 0.542 & 0.967 & 1989 & $\begin{array}{c}-1.202 * * \\
(0.110)\end{array}$ & $\begin{array}{c}0.021 \\
(0.015)\end{array}$ & $\begin{array}{l}-0.079 \\
(0.072)\end{array}$ & $\begin{array}{c}-0.122 * * \\
(0.009)\end{array}$ & $\begin{array}{c}-0.143^{* *} \\
(0.107)\end{array}$ & 0.898 & 0.919 & Kinked \\
\hline 70. Burma (Myanmar) & $\begin{array}{c}-1.978 \text { ** } \\
(0.195)\end{array}$ & $\begin{array}{c}-0.100^{*} \\
(0.048)\end{array}$ & 0.233 & 0.933 & 2009 & $\begin{array}{c}-2.211^{* *} \\
(0.106)\end{array}$ & $\begin{array}{l}-0.032 \\
(0.027)\end{array}$ & $\begin{array}{c}0.652 \\
(3.327)\end{array}$ & $\begin{array}{l}-0.657 \\
(0.602)\end{array}$ & $\begin{array}{l}-0.625 \\
(0.602)\end{array}$ & 0.793 & 0.634 & Classical \\
\hline 71. Yemen & $\begin{array}{c}-0.443^{*} \\
(0.175)\end{array}$ & $\begin{array}{c}-0.100^{* *} \\
(0.033)\end{array}$ & 0.344 & 0.933 & 1993 & $\begin{array}{c}-1.062 * * \\
(0.132)\end{array}$ & $\begin{array}{l}0.087^{* *} \\
(0.031)\end{array}$ & $\begin{array}{l}-0.876^{*} \\
(0.348)\end{array}$ & $\begin{array}{l}-0.032 \\
(0.064)\end{array}$ & $\begin{array}{l}-0.119 \\
(0.071)\end{array}$ & 0.871 & 0.978 & Classical \\
\hline 72. United Arab Emirates & $\begin{array}{c}-1.294^{* *} \\
(0.308)\end{array}$ & $\begin{array}{l}0.165 * * \\
(0.043)\end{array}$ & 0.477 & 1.121 & 1986 & $\begin{array}{c}-2.268^{* *} \\
(0.650)\end{array}$ & $\begin{array}{l}0.338^{*} \\
(0.134)\end{array}$ & $\begin{array}{l}0.612^{*} \\
(0.245)\end{array}$ & $\begin{array}{c}-0.095^{*} \\
(0.035)\end{array}$ & $\begin{array}{c}-0.4333^{* *} \\
(0.138)\end{array}$ & 0.892 & 0.936 & Kinked \\
\hline 73. Egypt & $\begin{array}{c}-0.726^{* *} \\
(0.205)\end{array}$ & $\begin{array}{l}-0.008 \\
(0.028)\end{array}$ & 0.012 & 0.994 & 1988 & $\begin{array}{c}-1.476^{* *} \\
(0.060)\end{array}$ & $\begin{array}{l}0.136^{* *} \\
(0.011)\end{array}$ & $\begin{array}{l}-0.088 \\
(0.082)\end{array}$ & $\begin{array}{c}-0.094^{* *} \\
(0.012)\end{array}$ & $\begin{array}{c}-0.230^{* *} \\
(0.016)\end{array}$ & 0.844 & 0.937 & Kinked \\
\hline 74. Tunisia & $\begin{array}{c}-0.680^{* *} \\
(0.174)\end{array}$ & $\begin{array}{l}-0.086^{*} \\
(0.035)\end{array}$ & 0.277 & 0.942 & 2007 & $\begin{array}{c}-0.950 * * \\
(0.082)\end{array}$ & $\begin{array}{l}-0.02 \\
(0.017)\end{array}$ & $\begin{array}{l}-0.843 \\
(4.754)\end{array}$ & $\begin{array}{l}-0.103 \\
(0.774)\end{array}$ & $\begin{array}{l}-0.082 \\
(0.775)\end{array}$ & 0.86 & 0.931 & Classical \\
\hline 75. Guyana & $\begin{array}{c}-0.608^{* *} \\
(0.087)\end{array}$ & $\begin{array}{c}-0.084^{* *} \\
(0.028)\end{array}$ & 0.145 & 0.943 & 1989 & $\begin{array}{c}-0.668^{* *} \\
(0.133)\end{array}$ & $\begin{array}{c}0.003 \\
(0.075)\end{array}$ & $\begin{array}{c}-1.441 \text { ** } \\
(0.232)\end{array}$ & $\begin{array}{l}0.166^{*} \\
(0.073)\end{array}$ & $\begin{array}{c}0.163 \\
(0.105)\end{array}$ & 0.5 & 1.122 & Classical \\
\hline 76. Indonesia & $\begin{array}{c}-1.267^{* *} \\
(0.125)\end{array}$ & $\begin{array}{l}0.056 \text { ** } \\
(0.016)\end{array}$ & 0.521 & 1.04 & 1999 & $\begin{array}{c}-1.072 * * \\
(0.142)\end{array}$ & $\begin{array}{c}0.024 \\
(0.020)\end{array}$ & $\begin{array}{l}-0.126 \\
(0.240)\end{array}$ & $\begin{array}{c}-0.075^{*} \\
(0.028)\end{array}$ & $\begin{array}{c}-0.099 * * \\
(0.034)\end{array}$ & 0.728 & 0.949 & Kinked \\
\hline 77. Korea, South & $\begin{array}{l}0.123^{*} \\
(0.054)\end{array}$ & $\begin{array}{c}-0.076^{* *} \\
(0.007)\end{array}$ & 0.689 & 0.949 & 1991 & $\begin{array}{c}0.258 \\
(0.134)\end{array}$ & $\begin{array}{c}-0.100 \text { ** } \\
(0.020)\end{array}$ & $\begin{array}{l}0.814^{*} \\
(0.305)\end{array}$ & $\begin{array}{c}-0.154^{* *} \\
(0.035)\end{array}$ & $\begin{array}{l}-0.054 \\
(0.040)\end{array}$ & 0.818 & 0.899 & Classical \\
\hline 78. Algeria & $\begin{array}{l}-0.271 \\
(0.158)\end{array}$ & $\begin{array}{c}-0.073^{* *} \\
(0.023)\end{array}$ & 0.291 & 0.951 & 2001 & $\begin{array}{c}-0.672 * * \\
(0.201)\end{array}$ & $\begin{array}{l}-0.003 \\
(0.030)\end{array}$ & $\begin{array}{c}-2.970^{*} \\
(1.133)\end{array}$ & $\begin{array}{c}0.268 \\
(0.146)\end{array}$ & $\begin{array}{c}0.271 \\
(0.149)\end{array}$ & 0.744 & 1.204 & Classical \\
\hline 79. Sao Tome and Principe & $\begin{array}{c}-1.090 * * \\
(0.038)\end{array}$ & $\begin{array}{l}0.279 * * \\
(0.026)\end{array}$ & 0.712 & 1.213 & 1990 & $\begin{array}{c}-1.577^{* *} \\
(0.031)\end{array}$ & $\begin{array}{l}0.100 * * \\
(0.013)\end{array}$ & $\begin{array}{c}-0.974^{* *} \\
(0.014)\end{array}$ & $\begin{array}{l}-0.069^{*} \\
(0.027)\end{array}$ & $\begin{array}{c}-0.169^{* *} \\
(0.032)\end{array}$ & 0.98 & 0.953 & Kinked \\
\hline 80. Sri Lanka & $\begin{array}{c}-1.963 \text { ** } \\
(0.071)\end{array}$ & $\begin{array}{c}-0.060^{* *} \\
(0.017)\end{array}$ & 0.237 & 0.959 & 2008 & $\begin{array}{c}-2.049 \text { ** } \\
(0.085)\end{array}$ & $\begin{array}{l}-0.036 \\
(0.022)\end{array}$ & $\begin{array}{l}-0.475 \\
(1.763)\end{array}$ & $\begin{array}{l}-0.35 \\
(0.322)\end{array}$ & $\begin{array}{l}-0.314 \\
(0.322)\end{array}$ & 0.391 & 0.785 & Classical \\
\hline 81. Kenya & $\begin{array}{c}-1.626^{* *} \\
(0.086)\end{array}$ & $\begin{array}{c}-0.056^{* *} \\
(0.019)\end{array}$ & 0.354 & 0.962 & 1983 & $\begin{array}{c}-1.459^{* *} \\
(0.159)\end{array}$ & $\begin{array}{l}-0.09 \\
(0.062)\end{array}$ & $\begin{array}{c}-1.851^{* *} \\
(0.095)\end{array}$ & $\begin{array}{l}-0.009 \\
(0.019)\end{array}$ & $\begin{array}{c}0.081 \\
(0.065)\end{array}$ & 0.582 & 0.994 & Classical \\
\hline 82. Uruguay & $\begin{array}{c}-1.480^{* *} \\
(0.154)\end{array}$ & $\begin{array}{l}-0.040 \\
(0.036)\end{array}$ & 0.078 & 0.973 & 1998 & $\begin{array}{c}-1.089^{* *} \\
(0.064)\end{array}$ & $\begin{array}{c}-0.162^{\text {** }} \\
(0.016)\end{array}$ & $\begin{array}{c}-1.705^{*} \\
(0.654)\end{array}$ & $\begin{array}{c}0.019 \\
(0.134)\end{array}$ & $\begin{array}{c}0.181 \\
(0.135)\end{array}$ & 0.566 & 1.013 & Classical \\
\hline 83. Japan & $\begin{array}{l}-0.095 \\
(0.110)\end{array}$ & $\begin{array}{c}-0.106^{* *} \\
(0.011)\end{array}$ & 0.817 & 0.929 & 1987 & $\begin{array}{c}0.3 \\
(0.378)\end{array}$ & $\begin{array}{l}-0.152^{* *} \\
(0.046)\end{array}$ & $\begin{array}{c}-0.803^{* *} \\
(0.113)\end{array}$ & $\begin{array}{c}-0.034^{* *} \\
(0.012)\end{array}$ & $\begin{array}{l}0.118^{*} \\
(0.048)\end{array}$ & 0.922 & 0.977 & Kinked \\
\hline 84. Equador & $\begin{array}{c}-1.327^{* *} \\
(0.069)\end{array}$ & $\begin{array}{l}0.027^{*} \\
(0.013)\end{array}$ & 0.186 & 1.019 & 2010 & $\begin{array}{c}-1.281^{* *} \\
(0.053)\end{array}$ & $\begin{array}{c}0.016 \\
(0.010)\end{array}$ & 3.932 & -0.775 & $\begin{array}{l}-0.791 \\
(0.452)\end{array}$ & 0.455 & 0.584 & Classical \\
\hline 85. Burkina Faso & $\begin{array}{c}-2.790 \text { ** } \\
(0.030)\end{array}$ & $\begin{array}{l}0.038^{*} \\
(0.014)\end{array}$ & 0.169 & 1.027 & 1997 & $\begin{array}{c}-2.766^{* *} \\
(0.021)\end{array}$ & $\begin{array}{l}-0.007 \\
(0.014)\end{array}$ & $\begin{array}{c}-2.221 \text { ** } \\
(0.206)\end{array}$ & $\begin{array}{l}-0.151 \\
(0.075)\end{array}$ & $\begin{array}{l}-0.144 \\
(0.076)\end{array}$ & 0.508 & 0.901 & Classical \\
\hline 86. Hong Kong & $\begin{array}{c}-1.445^{* *} \\
(0.067)\end{array}$ & $\begin{array}{l}0.039 * * \\
(0.011)\end{array}$ & 0.236 & 1.027 & 1994 & $\begin{array}{c}-1.5488^{* *} \\
(0.088)\end{array}$ & $\begin{array}{l}0.064^{* *} \\
(0.017)\end{array}$ & $\begin{array}{c}-2.322 * * \\
(0.351)\end{array}$ & $\begin{array}{l}0.164^{* *} \\
(0.051)\end{array}$ & $\begin{array}{c}0.100 \\
(0.054)\end{array}$ & 0.463 & 1.12 & Classical \\
\hline 87. Ghana & $\begin{array}{c}-2.005^{* *} \\
(0.054)\end{array}$ & $\begin{array}{l}0.043 * * \\
(0.013)\end{array}$ & 0.25 & 1.03 & 1990 & $\begin{array}{c}-2.098^{* *} \\
(0.167)\end{array}$ & $\begin{array}{c}0.09 \\
(0.070)\end{array}$ & $\begin{array}{c}-2.028^{* *} \\
(0.109)\end{array}$ & $\begin{array}{c}0.047 \\
(0.026)\end{array}$ & $\begin{array}{l}-0.042 \\
(0.074)\end{array}$ & 0.302 & 1.033 & Classical \\
\hline
\end{tabular}


Table A1. Cont.

\begin{tabular}{|c|c|c|c|c|c|c|c|c|c|c|c|c|c|}
\hline \multirow{2}{*}{ Country } & \multicolumn{4}{|c|}{ Classical Experience Equation } & \multirow{2}{*}{$\begin{array}{c}\text { Kinked } \\
\text { year } \\
\end{array}$} & \multicolumn{7}{|c|}{ Kinked Experience Equation } & \multirow{2}{*}{$\begin{array}{c}\text { Model } \\
\text { Selection }\end{array}$} \\
\hline & $\log a$ & $b$ & $R^{2}$ & $\operatorname{PR}\left(=2^{b}\right)$ & & $\log a_{1}$ & $b_{1}$ & $\log a_{2}$ & $b_{2}$ & $b_{2}-b_{1}$ & $R^{2}$ & $\mathrm{PR}_{2}\left(=2^{b 2}\right)$ & \\
\hline 88. Malaysia & $\begin{array}{c}-1.060 \text { ** } \\
(0.101)\end{array}$ & $\begin{array}{l}0.048 \text { ** } \\
(0.014)\end{array}$ & 0.416 & 1.034 & 1983 & $\begin{array}{c}-0.883^{* *} \\
(0.065)\end{array}$ & $\begin{array}{l}-0.026 \\
(0.016)\end{array}$ & $\begin{array}{c}-0.789 * * \\
(0.107)\end{array}$ & $\begin{array}{c}0.01 \\
(0.015)\end{array}$ & $\begin{array}{c}0.036 \\
(0.022)\end{array}$ & 0.719 & 1.007 & Classical \\
\hline 89. Turkey & $\begin{array}{c}-1.569^{* *} \\
(0.086)\end{array}$ & $\begin{array}{l}0.058^{* *} \\
(0.011)\end{array}$ & 0.677 & 1.041 & 1982 & $\begin{array}{l}-0.416 \\
(1.739)\end{array}$ & $\begin{array}{c}-0.2 \\
(0.381)\end{array}$ & $\begin{array}{c}-1.543^{* *} \\
(0.070)\end{array}$ & $\begin{array}{l}0.055^{* *} \\
(0.009)\end{array}$ & $\begin{array}{c}0.255 \\
(0.381)\end{array}$ & 0.756 & 1.039 & Classical \\
\hline 90. Sudan and South Sudan & $\begin{array}{c}-2.156^{* *} \\
(0.087)\end{array}$ & $\begin{array}{l}0.066^{*} \\
(0.025)\end{array}$ & 0.128 & 1.047 & 2009 & $\begin{array}{c}-2.048^{* *} \\
(0.065)\end{array}$ & $\begin{array}{c}0.033 \\
(0.022)\end{array}$ & $\begin{array}{c}-1.318 \\
(13.636)\end{array}$ & $\begin{array}{l}-0.051 \\
(2.558)\end{array}$ & $\begin{array}{l}-0.083 \\
(2.558)\end{array}$ & 0.286 & 0.965 & Classical \\
\hline 91. Brazil & $\begin{array}{c}-2.030^{* *} \\
(0.107)\end{array}$ & $\begin{array}{l}0.071 * * \\
(0.013)\end{array}$ & 0.667 & 1.05 & 1990 & $\begin{array}{c}-1629^{* *} \\
(0.119)\end{array}$ & $\begin{array}{c}0.007 \\
(0.017)\end{array}$ & $\begin{array}{c}-1.626^{* *} \\
(0.163)\end{array}$ & $\begin{array}{c}0.024 \\
(0.019)\end{array}$ & $\begin{array}{c}0.018 \\
(0.025)\end{array}$ & 0.844 & 1.017 & Classical \\
\hline 92. Philippines & $\begin{array}{c}-1.751^{* *} \\
(0.165)\end{array}$ & $\begin{array}{l}0.073^{*} \\
(0.028)\end{array}$ & 0.21 & 1.052 & 1987 & $\begin{array}{c}-1.104^{* *} \\
(0.181)\end{array}$ & $\begin{array}{l}-0.083 * \\
(0.038)\end{array}$ & $\begin{array}{c}-1.140 \text { ** } \\
(0.374)\end{array}$ & $\begin{array}{l}-0.015 \\
(0.056)\end{array}$ & $\begin{array}{l}-0.068 \\
(0.068)\end{array}$ & 0.438 & 0.99 & Classical \\
\hline 93. Vietnam & $\begin{array}{c}-1.367^{* *} \\
(0.106)\end{array}$ & $\begin{array}{l}0.075^{* *} \\
(0.018)\end{array}$ & 0.359 & 1.053 & 2010 & $\begin{array}{c}-1.277^{* *} \\
(0.085)\end{array}$ & $\begin{array}{l}0.056^{* *} \\
(0.015)\end{array}$ & 5.576 & -0.853 & $\begin{array}{l}-0.909 \\
(4.359)\end{array}$ & 0.508 & 0.554 & Classical \\
\hline 94. American Samoa & $\begin{array}{c}-0.316^{* *} \\
(0.081)\end{array}$ & $\begin{array}{l}0.108^{* *} \\
(0.034)\end{array}$ & 0.405 & 1.078 & 1989 & $\begin{array}{l}-0.290 \\
(0.145)\end{array}$ & $\begin{array}{c}0.031 \\
(0.126)\end{array}$ & $\begin{array}{c}-0.296^{*} \\
(0.126)\end{array}$ & $\begin{array}{c}0.104 \\
(0.057)\end{array}$ & $\begin{array}{c}0.074 \\
(0.138)\end{array}$ & 0.452 & 1.075 & Classical \\
\hline 95. Saint Lucia & $\begin{array}{c}-1.723 * * \\
(0.052)\end{array}$ & $\begin{array}{l}0.117^{*} \\
(0.046)\end{array}$ & 0.323 & 1.084 & 2000 & $\begin{array}{c}-1.813^{* *} \\
(0.017)\end{array}$ & $\begin{array}{l}-0.056 \\
(0.031)\end{array}$ & $\begin{array}{c}-1.252^{* *} \\
(0.157)\end{array}$ & $\begin{array}{l}-0.072 \\
(0.089)\end{array}$ & $\begin{array}{l}-0.017 \\
(0.094)\end{array}$ & 0.933 & 0.951 & Classical \\
\hline 96. Qatar & $\begin{array}{c}-1.328^{* *} \\
(0.118)\end{array}$ & $\begin{array}{l}0.123 * * \\
(0.015)\end{array}$ & 0.755 & 1.089 & 1989 & $\begin{array}{c}-1.611^{* *} \\
(0.546)\end{array}$ & $\begin{array}{l}0.171^{*} \\
(0.079)\end{array}$ & $\begin{array}{c}-1.945^{* *} \\
(0.294)\end{array}$ & $\begin{array}{l}0.195^{* *} \\
(0.035)\end{array}$ & $\begin{array}{c}0.024 \\
(0.086)\end{array}$ & 0.84 & 1.145 & Classical \\
\hline 97. Kuwait & $\begin{array}{c}-1.305^{* *} \\
(0.112)\end{array}$ & $\begin{array}{l}0.125^{* * *} \\
(0.017)\end{array}$ & 0.269 & 1.091 & 1992 & $\begin{array}{c}-1.925^{*} \\
(0.760)\end{array}$ & $\begin{array}{c}0.261 \\
(0.160)\end{array}$ & $\begin{array}{c}-1.862^{*} \\
(0.805)\end{array}$ & $\begin{array}{c}0.203 \\
(0.116)\end{array}$ & $\begin{array}{l}-0.057 \\
(0.197)\end{array}$ & 0.375 & 1.151 & Classical \\
\hline 98. Mauritius & $\begin{array}{c}-2.194 * * \\
(0.084)\end{array}$ & $\begin{array}{l}0.127^{* * *} \\
(0.025)\end{array}$ & 0.688 & 1.092 & 2000 & $\begin{array}{c}-2.177^{* *} \\
(0.112)\end{array}$ & $\begin{array}{l}0.114^{*} \\
(0.042)\end{array}$ & $\begin{array}{c}-1.367^{* *} \\
(0.338)\end{array}$ & $\begin{array}{l}-0.072 \\
(0.083)\end{array}$ & $\begin{array}{l}-0.186 \\
(0.093)\end{array}$ & 0.727 & 0.951 & Classical \\
\hline 99. Seychelles & $\begin{array}{c}-1.181^{* *} \\
(0.055)\end{array}$ & $\begin{array}{l}0.167^{* * *} \\
(0.028)\end{array}$ & 0.591 & 1.123 & 1983 & $\begin{array}{c}-1.740 * * \\
(0.000)\end{array}$ & $\begin{array}{c}-0.249 * * \\
(0.000)\end{array}$ & $\begin{array}{c}-1.101^{* *} \\
(0.049)\end{array}$ & $\begin{array}{l}0.129 * * \\
(0.028)\end{array}$ & $\begin{array}{l}0.378^{* *} \\
(0.028)\end{array}$ & 0.666 & 1.094 & Kinked \\
\hline 100. Cayman Island & $\begin{array}{c}-1.324^{* *} \\
(0.049)\end{array}$ & $\begin{array}{l}0.145^{* *} \\
(0.145)\end{array}$ & 0.802 & 1.106 & 1988 & $\begin{array}{c}-1.719^{* *} \\
(0.081)\end{array}$ & $\begin{array}{l}-0.145 \\
(0.111)\end{array}$ & $\begin{array}{c}-1.090 * * \\
(0.060)\end{array}$ & $\begin{array}{c}0.01 \\
(0.049)\end{array}$ & $\begin{array}{c}0.155 \\
(0.122)\end{array}$ & 0.802 & 1.007 & Classical \\
\hline 101. Bolivia & $\begin{array}{c}-1.915 \text { ** } \\
(0.117)\end{array}$ & $\begin{array}{l}0.151^{* *} \\
(0.026)\end{array}$ & 0.691 & 1.11 & 2001 & $\begin{array}{c}-1.545^{* *} \\
(0.065)\end{array}$ & $\begin{array}{c}0.018 \\
(0.022)\end{array}$ & $\begin{array}{l}-1.542 \\
(1.134)\end{array}$ & $\begin{array}{c}0.083 \\
(0.213)\end{array}$ & $\begin{array}{c}0.09 \\
(0.044)\end{array}$ & 0.832 & 1.059 & Classical \\
\hline 102. Iran & $\begin{array}{c}-1.751^{* *} \\
(0.093)\end{array}$ & $\begin{array}{l}0.155^{* *} \\
(0.011)\end{array}$ & 0.892 & 1.113 & 1986 & $\begin{array}{c}-1.709 * * \\
(0.284)\end{array}$ & $\begin{array}{l}0.140 * * \\
(0.045)\end{array}$ & $\begin{array}{c}-1.302 \text { ** } \\
(0.158)\end{array}$ & $\begin{array}{l}0.101 * * \\
(0.019)\end{array}$ & $\begin{array}{l}-0.039 \\
(0.048)\end{array}$ & 0.938 & 1.073 & Classical \\
\hline 103. Guatemala & $\begin{array}{c}-2.486^{* *} \\
(0.178)\end{array}$ & $\begin{array}{l}0.159 * * \\
(0.040)\end{array}$ & 0.567 & 1.117 & 1994 & $\begin{array}{c}-1.905^{* *} \\
(0.121)\end{array}$ & $\begin{array}{l}-0.051 \\
(0.039)\end{array}$ & $\begin{array}{c}-2.205^{* *} \\
(0.325)\end{array}$ & $\begin{array}{c}0.111 \\
(0.067)\end{array}$ & $\begin{array}{l}0.162^{*} \\
(0.077)\end{array}$ & 0.861 & 1.08 & Classical \\
\hline 104. Bangladesh & $\begin{array}{c}-3.119^{* *} \\
(0.094)\end{array}$ & $\begin{array}{l}0.165^{* * *} \\
(0.017)\end{array}$ & 0.918 & 1.121 & 1992 & $\begin{array}{c}-2.949 * * \\
(0.160)\end{array}$ & $\begin{array}{l}0.116^{* *} \\
(0.038)\end{array}$ & $\begin{array}{c}-3.107^{* *} \\
(0.152)\end{array}$ & $\begin{array}{l}0.164 \text { ** } \\
(0.026)\end{array}$ & $\begin{array}{c}0.048 \\
(0.046)\end{array}$ & 0.936 & 1.12 & Classical \\
\hline 105. Saint Vincent Grenadines & $\begin{array}{c}-1.921 \text { ** } \\
(0.031)\end{array}$ & $\begin{array}{l}0.172 * * \\
(0.038)\end{array}$ & 0.58 & 1.127 & 1994 & $\begin{array}{c}-2.259 * * \\
(0.088)\end{array}$ & $\begin{array}{l}-0.008 \\
(0.056)\end{array}$ & $\begin{array}{c}-1.704^{* *} \\
(0.035)\end{array}$ & $\begin{array}{l}-0.035 \\
(0.039)\end{array}$ & $\begin{array}{l}-0.027 \\
(0.068)\end{array}$ & 0.851 & 0.976 & Classical \\
\hline 106. Thailand & $\begin{array}{c}-1.963^{* *} \\
(0.156)\end{array}$ & $\begin{array}{l}0.161 * * \\
(0.161)\end{array}$ & 0.887 & 1.118 & 1990 & $\begin{array}{c}-1.358^{* *} \\
(0.263)\end{array}$ & $\begin{array}{c}0.038 \\
(0.048)\end{array}$ & $\begin{array}{c}-2.072 * * \\
(0.107)\end{array}$ & $\begin{array}{l}0.177^{* *} \\
(0.014)\end{array}$ & $\begin{array}{l}0.139 * * \\
(0.050)\end{array}$ & 0.951 & 1.131 & Kinked \\
\hline 107. Grenada & $\begin{array}{c}-1.659 \text { ** } \\
(0.033)\end{array}$ & $\begin{array}{l}0.185^{* *} \\
(0.022)\end{array}$ & 0.616 & 1.137 & 1999 & $\begin{array}{c}-1.631 \text { ** } \\
(0.039)\end{array}$ & $\begin{array}{l}0,198^{* *} \\
(0.037)\end{array}$ & $\begin{array}{c}-2.259 * * \\
(0.449)\end{array}$ & $\begin{array}{c}0.648 \\
(0.316)\end{array}$ & $\begin{array}{c}0.449 \\
(0.319)\end{array}$ & 0.701 & 1.567 & Classical \\
\hline 108. Nicaragua & $\begin{array}{c}-1.684^{* *} \\
(0.113)\end{array}$ & $\begin{array}{l}0.195 * * \\
(0.031)\end{array}$ & 0.78 & 1.145 & 1992 & $\begin{array}{c}-1.559^{* *} \\
(0.184)\end{array}$ & $\begin{array}{c}0.12 \\
(0.071)\end{array}$ & $\begin{array}{l}-1.09 * * \\
(0.169)\end{array}$ & $\begin{array}{c}0.054 \\
(0.043)\end{array}$ & $\begin{array}{l}-0.066 \\
(0.083)\end{array}$ & 0.879 & 1.038 & Classical \\
\hline 109. Dominica & $\begin{array}{c}-1.908^{* *} \\
(0.022)\end{array}$ & $\begin{array}{l}0.196 * * \\
(0.030)\end{array}$ & 0.781 & 1.146 & 2001 & $\begin{array}{c}-2.016^{* *} \\
(0.027)\end{array}$ & $\begin{array}{l}0.133 \text { ** } \\
(0.025)\end{array}$ & $\begin{array}{c}-1.689 * * \\
(0.105)\end{array}$ & $\begin{array}{l}-0.030 \\
(0.141)\end{array}$ & $\begin{array}{l}-0.163 \\
(0.143)\end{array}$ & 0.133 & 0.979 & Classical \\
\hline
\end{tabular}


Table A1. Cont.

\begin{tabular}{|c|c|c|c|c|c|c|c|c|c|c|c|c|c|}
\hline \multirow{2}{*}{ Country } & \multicolumn{4}{|c|}{ Classical Experience Equation } & \multirow{2}{*}{$\begin{array}{c}\text { Kinked } \\
\text { year }\end{array}$} & \multicolumn{7}{|c|}{ Kinked Experience Equation } & \multirow{2}{*}{$\begin{array}{c}\text { Model } \\
\text { Selection }\end{array}$} \\
\hline & $\log a$ & $b$ & $R^{2}$ & $\operatorname{PR}\left(=2^{b}\right)$ & & $\log a_{1}$ & $b_{1}$ & $\log a_{2}$ & $b_{2}$ & $b_{2}-b_{1}$ & $R^{2}$ & $\mathrm{PR}_{2}\left(=2^{b 2}\right)$ & \\
\hline 110. Trinidad and Tobago & $\begin{array}{c}-0.872 * * \\
(0.224)\end{array}$ & $\begin{array}{l}0.196 * * \\
(0.039)\end{array}$ & 0.626 & 1.146 & 1998 & $\begin{array}{c}-1.478^{* *} \\
(0.282)\end{array}$ & $\begin{array}{l}0.342 * * \\
(0.055)\end{array}$ & $\begin{array}{l}-0.038 \\
(0.531)\end{array}$ & $\begin{array}{c}0.049 \\
(0.083)\end{array}$ & $\begin{array}{c}-0.293 * * \\
(0.100)\end{array}$ & 0.874 & 1.035 & Classical \\
\hline 111. Oman & $\begin{array}{c}-1.893 \text { ** } \\
(0.154)\end{array}$ & $\begin{array}{l}0.196^{* * *} \\
(0.031)\end{array}$ & 0.776 & 1.146 & 2005 & $\begin{array}{c}-1.680^{* *} \\
(0.111)\end{array}$ & $\begin{array}{l}0.138 * * \\
(0.023)\end{array}$ & $\begin{array}{l}-3.805^{*} \\
(1.202)\end{array}$ & $\begin{array}{l}0.530^{*} \\
(0.198)\end{array}$ & $\begin{array}{c}0.392 \\
(0.200)\end{array}$ & 0.915 & 1.444 & Classical \\
\hline 112. Martinique & $\begin{array}{c}-2.006 \text { ** } \\
(0.103)\end{array}$ & $\begin{array}{l}0.200 * * \\
(0.032)\end{array}$ & 0.69 & 1.149 & 1989 & $\begin{array}{c}-1.914 * * \\
(0.104)\end{array}$ & $\begin{array}{c}0.001 \\
(0.092)\end{array}$ & $\begin{array}{c}-1.438^{* *} \\
(0.150)\end{array}$ & $\begin{array}{c}0.037 \\
(0.042)\end{array}$ & $\begin{array}{c}0.035 \\
(0.101)\end{array}$ & 0.884 & 1.026 & Classical \\
\hline 113. Cape Verde & $\begin{array}{c}-1.968^{* *} \\
(0.166)\end{array}$ & $\begin{array}{l}-0.454^{*} \\
(0.171)\end{array}$ & 0.381 & 0.73 & 1986 & $\begin{array}{c}-1.683^{* *} \\
(0.115)\end{array}$ & $\begin{array}{c}-0.817 * * \\
(0.271)\end{array}$ & $\begin{array}{c}-2.684^{* *} \\
(0.078)\end{array}$ & $\begin{array}{l}0.204^{* * *} \\
(0.067)\end{array}$ & $\begin{array}{l}1.021^{* *} \\
(0.279)\end{array}$ & 0.853 & 1.152 & Kinked \\
\hline 114. El Salvador & $\begin{array}{c}-4.325 \text { ** } \\
(0.423)\end{array}$ & $\begin{array}{l}0.231^{* *} \\
(0.041)\end{array}$ & 0.799 & 1.174 & 1995 & $\begin{array}{c}-3.650 * * \\
(0.582)\end{array}$ & $\begin{array}{l}0.154^{*} \\
(0.060)\end{array}$ & $\begin{array}{l}-0.747 \\
(0.798)\end{array}$ & $\begin{array}{l}-0.098 \\
(0.074)\end{array}$ & $\begin{array}{l}-0.253^{*} \\
(0.095)\end{array}$ & 0.927 & 0.934 & Classical \\
\hline 115. Cambodia & $\begin{array}{c}-3.556 \text { ** } \\
(0.149)\end{array}$ & $\begin{array}{l}0.389 * * \\
(0.054)\end{array}$ & 0.79 & 1.309 & 1983 & $\begin{array}{c}-5.105^{* *} \\
(0.003)\end{array}$ & $\begin{array}{l}0.003^{*} \\
(0.001)\end{array}$ & $\begin{array}{c}-3.161^{* *} \\
(0.120)\end{array}$ & $\begin{array}{l}0.235^{* * *} \\
(0.038)\end{array}$ & $\begin{array}{l}0.232 \text { ** } \\
(0.039)\end{array}$ & 0.894 & 1.177 & Kinked \\
\hline 116. Comoros & $\begin{array}{c}-2.537^{* * *} \\
(0.020)\end{array}$ & $\begin{array}{l}0.236^{* *} \\
(0.052)\end{array}$ & 0.745 & 1.178 & 2007 & $\begin{array}{c}-2.570 * * \\
(0.021)\end{array}$ & $\begin{array}{l}0.211^{* *} \\
(0.057)\end{array}$ & $\begin{array}{c}-2.250 * \\
(0.701)\end{array}$ & $\begin{array}{c}0.012 \\
(0.786)\end{array}$ & $\begin{array}{l}-0.199 \\
(0.788)\end{array}$ & 0.773 & 1.008 & Classical \\
\hline 117. Libya & $\begin{array}{c}-2.008^{* *} \\
(0.142)\end{array}$ & $\begin{array}{l}0.241 \text { ** } \\
(0.023)\end{array}$ & 0.79 & 1.182 & 1986 & $\begin{array}{c}-1.473^{* *} \\
(0.221)\end{array}$ & $\begin{array}{l}0.103^{*} \\
(0.047)\end{array}$ & $\begin{array}{c}-1.360 * * \\
(0.287)\end{array}$ & $\begin{array}{l}0.144^{* * *} \\
(0.045)\end{array}$ & $\begin{array}{c}0.041 \\
(0.065)\end{array}$ & 0.868 & 1.105 & Classical \\
\hline 118. Tonga & $\begin{array}{c}-1.577^{* *} \\
(0.028)\end{array}$ & $\begin{array}{l}0.274^{* *} \\
(0.022)\end{array}$ & 0.831 & 1.209 & 2006 & $\begin{array}{c}-1.602 * * \\
(0.036)\end{array}$ & $\begin{array}{l}0.255^{* *} \\
(0.026)\end{array}$ & $\begin{array}{c}-1.119^{*} \\
(0.272)\end{array}$ & $\begin{array}{l}-0.073 \\
(0.234)\end{array}$ & $\begin{array}{l}-0.329 \\
(0.236)\end{array}$ & 0.844 & 0.951 & Classical \\
\hline 119. Tanzania & $\begin{array}{c}-1.509 * * \\
(0.098)\end{array}$ & $\begin{array}{c}-0.084^{* *} \\
(0.027)\end{array}$ & 0.319 & 0.943 & 1996 & $\begin{array}{c}-1.552 * * \\
(0.159)\end{array}$ & $\begin{array}{l}-0.055 \\
(0.055)\end{array}$ & $\begin{array}{c}-3.045 * * \\
(0.219)\end{array}$ & $\begin{array}{l}0.275^{* * *} \\
(0.053)\end{array}$ & $\begin{array}{l}0.330^{* * *} \\
(0.077)\end{array}$ & 0.683 & 1.21 & Kinked \\
\hline 120. Honduras & $\begin{array}{c}-2.430^{* * *} \\
(0.142)\end{array}$ & $\begin{array}{l}0.228 * * \\
(0.037)\end{array}$ & 0.808 & 1.171 & 1989 & $\begin{array}{c}-1.980 * * \\
(0.109)\end{array}$ & $\begin{array}{l}-0.024 \\
(0.050)\end{array}$ & $\begin{array}{c}-2.617^{* *} \\
(0.135)\end{array}$ & $\begin{array}{l}0.279^{* * *} \\
(0.035)\end{array}$ & $\begin{array}{l}0.303^{* *} \\
(0.061)\end{array}$ & 0.92 & 1.213 & Kinked \\
\hline 121. Guinea-Bissau & $\begin{array}{c}-1.482 * * \\
(0.049)\end{array}$ & $\begin{array}{l}0.282 * * \\
(0.034)\end{array}$ & 0.856 & 1.216 & 1987 & $\begin{array}{c}-1.887^{* *} \\
(0.144)\end{array}$ & $\begin{array}{c}0.035 \\
(0.132)\end{array}$ & $\begin{array}{c}-1.326 * * \\
(0.034)\end{array}$ & $\begin{array}{l}0.188^{* * *} \\
(0.024)\end{array}$ & $\begin{array}{c}0.153 \\
(0.134)\end{array}$ & 0.941 & 1.139 & Classical \\
\hline 122. Togo & $\begin{array}{c}-2.232 * * \\
(0.160)\end{array}$ & $\begin{array}{l}0.284 \text { ** } \\
(0.071)\end{array}$ & 0.439 & 1.218 & 1999 & $\begin{array}{c}-1.891 * * \\
(0.048)\end{array}$ & $\begin{array}{l}-0.021 \\
(0.029)\end{array}$ & $\begin{array}{l}-2.142 * \\
(0.942)\end{array}$ & $\begin{array}{c}0.315 \\
(0.313)\end{array}$ & $\begin{array}{c}0.336 \\
(0.315)\end{array}$ & 0.754 & 1.244 & Classical \\
\hline 123. Congo (Brazzaville) & $\begin{array}{c}-2.173 * * \\
(0.170)\end{array}$ & $\begin{array}{l}0.320 * * \\
(0.047)\end{array}$ & 0.698 & 1.248 & 1991 & $\begin{array}{c}-1.794 * * \\
(0.095)\end{array}$ & $\begin{array}{l}-0.077 \\
(0.067)\end{array}$ & $\begin{array}{c}-1.295^{* *} \\
(0.176)\end{array}$ & $\begin{array}{c}0.104 \\
(0.050)\end{array}$ & $\begin{array}{l}0.181^{*} \\
(0.084)\end{array}$ & 0.899 & 1.075 & Classical \\
\hline 124. Maldives & $\begin{array}{c}-1.496^{* *} \\
(0.051)\end{array}$ & $\begin{array}{l}0.400 * * \\
(0.029)\end{array}$ & 0.891 & 1.32 & 1984 & $\begin{array}{c}-3.506 \text { ** } \\
(0.056)\end{array}$ & $\begin{array}{c}-0.120^{* *} \\
(0.018)\end{array}$ & $\begin{array}{c}-1.432 * * \\
(0.054)\end{array}$ & $\begin{array}{l}0.347^{* * *} \\
(0.031)\end{array}$ & $\begin{array}{l}0.467^{* *} \\
(0.036)\end{array}$ & 0.922 & 1.272 & Kinked \\
\hline 125. Haiti & $\begin{array}{c}-3.897 \text { ** } \\
(0.179)\end{array}$ & $\begin{array}{l}0.353^{* *} \\
(0.062)\end{array}$ & 0.665 & 1.277 & 1982 & $\begin{array}{c}-3.568 * * \\
(0.411)\end{array}$ & $\begin{array}{l}-0.740 \\
(1.522)\end{array}$ & $\begin{array}{c}-4.097^{* *} \\
(0.156)\end{array}$ & $\begin{array}{l}0.423^{* * *} \\
(0.048)\end{array}$ & $\begin{array}{c}1.162 \\
(1.523)\end{array}$ & 0.726 & 1.341 & Classical \\
\hline 126. Benin & $\begin{array}{c}-2.715 \text { ** } \\
(0.171)\end{array}$ & $\begin{array}{l}0.356^{* * *} \\
(0.067)\end{array}$ & 0.794 & 1.28 & 1987 & $\begin{array}{c}-2.465 \text { ** } \\
(0.131)\end{array}$ & $\begin{array}{l}-0.03 \\
(0.166)\end{array}$ & $\begin{array}{c}-3.269 * * \\
(0.060)\end{array}$ & $\begin{array}{l}0.555^{* * *} \\
(0.024)\end{array}$ & $\begin{array}{l}0.585^{* * *} \\
(0.168)\end{array}$ & 0.951 & 1.469 & Kinked \\
\hline 127. Lebanon & $\begin{array}{c}-1.893^{* *} \\
(0.154)\end{array}$ & $\begin{array}{l}0.196^{* *} \\
(0.031)\end{array}$ & 0.776 & 1.146 & 2001 & $\begin{array}{c}-1.669^{* *} \\
(0.129)\end{array}$ & $\begin{array}{l}0.134^{* *} \\
(0.029)\end{array}$ & $\begin{array}{c}-4.698^{* *} \\
(0.624)\end{array}$ & $\begin{array}{l}0.672 * * \\
(0.105)\end{array}$ & $\begin{array}{l}0.537^{* *} \\
(0.109)\end{array}$ & 0.907 & 1.593 & Kinked \\
\hline
\end{tabular}




\section{References}

1. Olivier, J.G.J.; Janssens-Maenhout, O.; Muntean, M.; Peters, J.A.H.W. Trend in Global $\mathrm{CO}_{2}$ Emissions 2016 Report; PBL Netherlands Environment Agency: The Hague, The Netherlands, 2016.

2. Albion, V.; Ardito, L.; Dangelico, R.M.; Messeni Petruzzelli, A. Understanding the development trends of low-carbon energy technologies: A patent analysis. Appl. Energy 2014, 135, 836-854. [CrossRef]

3. Zhu, Z.-H.; Liao, H.; Cao, H.-S.; Wang, L.; Wei, Y.-M.; Yan, J. The differences of carbon intensity reduction rate across 89 countries in recent three decades. Appl. Energy 2014, 113, 808-815. [CrossRef]

4. Rodriguez, M.; Pena-Boquete, Y. Carbon intensity changes in the Asian Dragons. Lessons for climate policy design. Energy Econ. 2017, 66, 17-26. [CrossRef]

5. Wang, H.; Ang, B.W.; Su, B. A multi-region structural decomposition analysis of global $\mathrm{CO}_{2}$ emission intensity. Ecol. Econ. 2017, 142, 163-176. [CrossRef]

6. Du, K.; Xie, C.; Ouyang, X. A comparison of carbon dioxide $\left(\mathrm{CO}_{2}\right)$ emission trends among provinces in China. Renew. Sustain. Energy Rev. 2017, 73, 19-25. [CrossRef]

7. PwC. Low Carbon Economy Index. 2009. Available online: https://www.pwc.com/gx/en/sustainability/ publications/low-carbon-economy-index/assets/low-carbon-economy-index.pdf (accessed on 27 January 2017).

8. PwC. The Paris Agreement: A Turning Point? The Low Carbon Economy Index. 2016. Available online: https: //www.pwc.com/gx/en/psrc/publications/assets/the-paris-agreement.pdf (accessed on 27 January 2017).

9. Feng, K.S.; Klaus, H.; Guan, D.B. Lifestyles, technology and $\mathrm{CO}_{2}$ emissions in China: A regional comparative analysis. Ecol. Econ. 2009, 69, 145-154. [CrossRef]

10. Zhang, M. Decomposition of energy-related $\mathrm{CO}_{2}$ emission over 1991-2006 in China. Ecol. Econ. 2009, 68, 2122-2128. [CrossRef]

11. Zhang, M. Accounting for energy-related $\mathrm{CO}_{2}$ emission in China 1991-2006. Energy Policy 2009, 37, 767-773. [CrossRef]

12. Zha, D.L.; Zhou, D.Q.; Zhou, P. Driving forces of residential $\mathrm{CO}_{2}$ emission in urban and rural China: An index decomposition analysis. Energy Policy 2010, 38, 3377-3383.

13. Akbostanci, E.; Tunç, G.İ.; Türüt-Aşik, S. $\mathrm{CO}_{2}$ emissions of Turkish manufacturing industry: A decomposition analysis. Appl. Energy 2011, 88, 2273-2278. [CrossRef]

14. Wright, T. Factors affecting the cost of airplanes. J. Aeronaut. Sci. 1936, 3, 122-128. [CrossRef]

15. Nakicenovic, N. Technological change and learning. Perspect. Energy 1997, 4, 173-190.

16. International Energy Agency (IEA). Experience Curves for Energy Technology Policy; International Energy Agency (IEA): Paris, France, 2000.

17. Weiss, M.; Junginger, M.; Patel, M.K.; Blok, K. A review of experience curve analyses for energy demand technologies. Technol. Forecast. Soc. 2010, 77, 411-428. [CrossRef]

18. McDonald, A.; Schrattenholzer, L. Learning rates for energy technologies. Energy Policy 2001, 29, $255-261$. [CrossRef]

19. Junginger, M.; Lako, P.; Lensink, S.; Van Sark, W.; Weiss, M. Technological Learning in the Energy Sector. In Climate Change Scientific Assessment and Policy Analysis; Report 500102017; Environmental Assessment Agency: Bilthoven, The Netherlands, 2008.

20. Kahouli-Brahmi, S. Technological learning in energy-environment-economy modeling: A survey. Energy Policy 2008, 36, 138-162. [CrossRef]

21. Rubin, E.S.; Azevedo, M.L.; Jaramillo, P.; Yeh, S. A review of learning rates for electricity supply technologies. Energy Policy 2015, 86, 198-218. [CrossRef]

22. Rout, U.K.; Blesl, M.; Fahl, U.; Remme, U.; Vob, A. Uncertainty in the learning rates of energy technologies: An experiment in a global multi-regional energy system model. Energy Policy 2009, 37, 4927-4942. [CrossRef]

23. Sagar, A.; Van der Zwaan, B.C.C. Technological innovation in the energy sector: R\&D, deployment and learning-by-doing. Energy Policy 2006, 34, 2601-2608.

24. Rosenberg, N. Inside the Black Box: Technology and Economics; Cambridge University Press: Cambridge, UK, 1986.

25. Rotmans, J.; Kemp, R. Managing societal transitions: Dilemmas and uncertainties, the Dutch energy case study. In Proceedings of the OECD Workshop on the Benefits of Climate Policy: Improving Information for Policy Makers, Paris, France, 12-13 September 2003.

26. Grubler, A. The costs of the French nuclear scale-up: A case of negative learning by doing. Energy Policy 2010, 38, 5174-5188. [CrossRef] 
27. Kouvaritakis, N.; Soria, A.; Isoard, S. Modeling energy technology dynamics: Methodology for adaptive expectations models with learning by doing and learning by searching. Int. J. Glob. Energy 2000, 14, 104-115. [CrossRef]

28. Trappey, A.J.C.; Trappey, C.V.; Liu, P.H.Y.; Lin, L.-C.; Ou, J.J.R. A hierarchical cost learning model for developing wind energy infrastructures. Int. J. Prod. Econ. 2013, 146, 386-391. [CrossRef]

29. McDowall, W. Endogenous Technology Learning for Hydrogen and Fuel Cell Technology in UKSHEC II: Literature Review, Research Questions and Data; UKSHEC Working Paper No. 8; University College London: London, UK, 2012.

30. Neji, L.; Borup, M.; Blesl, M.; Mayer-Spohn, O. Cost Development-An Analysis Based on Experience Curves. New Energy Externalities Development for Sustainability; Project No. 502687; Lund University: Lund, Sweden, 2006.

31. Van Sark, W. Introducing errors in progress ratios determined from experience curves. Technol. Forecast. Soc. 2008, 75, 405-415. [CrossRef]

32. Chang, Y.; Lee, J.; Yoon, H. Alternative projection of the world energy consumption-In comparison with the 2010 international energy outlook. Energy Policy 2012, 50, 154-160. [CrossRef]

33. Wei, M.; Smith, S.J.; Sohn, M.D. Experience curve development and cost reduction disaggregation for fuel cell markets in Japan and the US. Appl. Energy 2017, 191, 346-357. [CrossRef]

34. Wei, M.; Smith, S.J.; Sohn, M.D. Non-constant learning rates in retrospective experience curve analyses and their correlation to deployment programs. Energy Policy 2017, 107, 356-369. [CrossRef]

35. Chang, Y.S.; Lee, J. Kinked experience curve. In Encyclopedia of Business Analysis and Optimization; Business Science Reference: Hershey, PA, USA, 2014; pp. 1358-1366.

36. Kaya, Y.; Yokobori, K. Environment, Energy, and Economy: Strategies for Sustainability; Technical Report Brook-0356/XAB; Brookings Institution: Washington, DC, USA, 1998.

37. U.S. Energy Information Administration. International Energy Statistics. Available online: https://www.eia. gov/beta/international/data/browser (accessed on 25 August 2016).

38. Chang, Y.; Lee, J. Forecasting road fatalities by the use of kinked experience curve. Int. J. Data Anal. Tech. Strateg. 2013, 5, 398-426. [CrossRef]

39. Chang, Y. Comparative analysis of long term road fatality targets for individual states in the US-An application of experience curve models. Transp. Policy 2014, 36, 53-69. [CrossRef]

40. Chang, Y.; Jeon, S. Using the experience curve model to project carbon dioxide emissions through 2040. Carbon Technol. 2015, 6, 51-62. [CrossRef]

41. Chang, Y.; Jo, S.; Jeon, S. Using experience curve to project net hydroelectricity generation: In comparison to EIAs projection. Int. J. Energy Technol. Policy 2017, 13, 305-319. [CrossRef]

42. Ardito, L.; Messeni Petruzzeilli, A.; Albino, V. Investigating the antecedents of general purpose technologies: A patent perspective in the green energy field. J. Eng. Technol. Manag. 2016, 39, 81-100. [CrossRef]

43. Nemet, G.F. Inter-technology knowledge spillovers for energy technologies. Energy Econ. 2012, 34, 1259-1270. [CrossRef]

(C) 2017 by the authors. Licensee MDPI, Basel, Switzerland. This article is an open access article distributed under the terms and conditions of the Creative Commons Attribution (CC BY) license (http:// creativecommons.org/licenses/by/4.0/). 